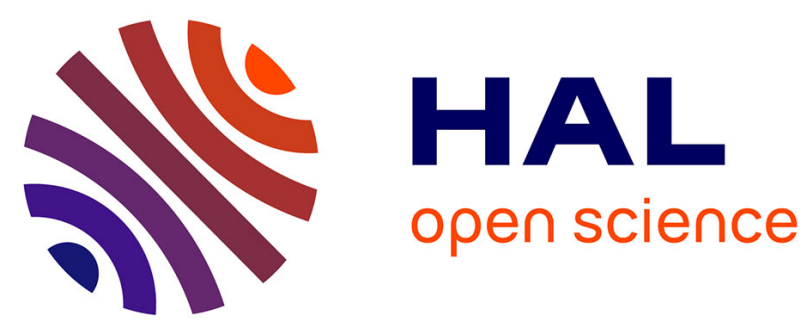

\title{
Illite-smectite mixed-layer minerals in hydrothermal alteration of volcanic rocks: I. One-dimensional XRD structure analysis and characterisation of component layers.
}

Atsuyuki Inoue, Bruno Lanson, M. Marques-Fernandes, B.A. Sakharov, T. Murakami, A. Meunier, Daniel Beaufort

\section{To cite this version:}

Atsuyuki Inoue, Bruno Lanson, M. Marques-Fernandes, B.A. Sakharov, T. Murakami, et al.. Illitesmectite mixed-layer minerals in hydrothermal alteration of volcanic rocks: I. One-dimensional XRD structure analysis and characterisation of component layers.. Clays and Clay Minerals, 2005, 53, pp.423-439. 10.1346/CCMN.2005.0530501 . hal-00107011

\section{HAL Id: hal-00107011 \\ https://hal.science/hal-00107011}

Submitted on 5 Dec 2007

HAL is a multi-disciplinary open access archive for the deposit and dissemination of scientific research documents, whether they are published or not. The documents may come from teaching and research institutions in France or abroad, or from public or private research centers.
L'archive ouverte pluridisciplinaire HAL, est destinée au dépôt et à la diffusion de documents scientifiques de niveau recherche, publiés ou non, émanant des établissements d'enseignement et de recherche français ou étrangers, des laboratoires publics ou privés. 


\section{ILLITE-SMECTITE MIXED-LAYER MINERALS IN HYDROTHERMAL ALTERATION OF VOLCANIC ROCKS: \\ I. ONE-DIMENSIONAL XRD STRUCTURE ANALYSIS AND CHARACTERIZATION OF COMPONENT LAYERS}

Atsuyuki Inoue ${ }^{1)}$, Bruno Lanson ${ }^{2)}$, Maria Marques-Fernandes ${ }^{2)}$, Boris A. Sakharov ${ }^{2,3)}$, Takashi Murakami ${ }^{4)}$, Alain Meunier ${ }^{5)}$ and Daniel Beaufort ${ }^{5)}$

1) Department of Earth Sciences, Chiba University, Chiba 263-8522, JAPAN

2) LGIT-Maison des GéoScience, BP53, Université de J. Fourier, 38041 Grenoble Cedex 9, FRANCE

3) Geological Institute, Russian Academy of Sciences, Pyzhevsky per. 7, 119017 Moscow, RUSSIA

4) Department of Earth and Planetary Science, The University of Tokyo, Tokyo 113-0033, JAPAN

5) HydrASA-UMR 6532 CNRS, Université de Poitiers, 40 av. Recteur Pineau, 86022 Poitiers Cedex, FRANCE

Running Title: XRD characterization of hydrothermal I-S mixed-layer minerals

The person to whom correspondence and page proofs should be sent:

Atsuyuki Inoue

Department of Earth Sciences, Chiba University, Chiba 263-8522, Japan

E-mail: atinoue@earth.s.chiba-u.ac.jp 


\section{Abstract}

For a series of mixed-layer illite-smectite (I-S) minerals from a drill hole near the Kakkonda geothermal field, one-dimensional structure analysis by X-ray diffraction (XRD) was performed using Ca-saturated specimens at both air-dried and ethylene glycol solvated states. The expandability characteristics of component layers were also examined by means of alkylammonium exchange and Li-saturation. The $\mathrm{K}$ content in illite layer was almost constant at $1.5-1.7 / \mathrm{O}_{20}(\mathrm{OH})_{4}$ in the I-S series from $3 \%$ to $85 \%$ of I-layer content (\% I). The layer charge of smectite layer varied slightly within the ranges of $<0.5 / \mathrm{O}_{10}(\mathrm{OH})_{2}$ by alkylammonium exchange experiments and the expandability was independent of the beidellite content within a range of 0-0.5 by Li-saturation test. The degree of long-range ordering represented by Reichweite (R) parameters varied consecutively from R0 to R3 via R1 and R2 with increase of \% I. The I-S samples contained $<10 \%$ vermiculite as the third component and the vermiculite content tended to decrease with progressive illitization.

In contrast to the smectitic R0 samples $(<10 \%$ I), more illitic R0 (e.g., 35\% I) and $>$ R1 I-S samples showed complicated expandability with alkylammonium exchange. The XRD patterns of dodecylammonium exchanged I-S samples can be interpreted by random interstratification of several types of sub-units such as layer-doublets, layer-triplets and layer-quarutets present in the crystallites. This interpretation is consistent with the variation in the occurrence probabilities of layer-multiplets calculated from the junction probabilities and the proportions of layers. Because the interpretation indicates that I-S is a stack of various types of the sub-units, the smectite illitization can be described by a systematic change in the type and proportion of the sub-units constituting crystallites.

Key words: Alkylammonium-exchange, expandability, hydrothermal system, illite-smectite mixed layer minerals, one-dimensional XRD structure analysis 


\section{INTRODUCTION}

Sequential smectite-to-illite reaction via their mixed-layer minerals (hereafter called smectite illitization) has been documented in low-temperature crustal environments and is commonly associated with burial diagenesis, low-grade metamorphism, contact metamorphism and hydrothermal alteration. Despite extensive investigation over the last several decades (see a recent review of Meunier and Velde, 2004), many unresolved points remain, including the crystal chemical models of illite-smectite (I-S) mixed-layering structures and the illitization mechanism. Previous X-ray diffraction (XRD) studies of I-S minerals documented that smectite illitization occurs with a continuous variation in the proportions of smectite (S) and illite (I) layers regardless of geologic environments (e.g., Hower et al., 1976 for diagenesis; Inoue et al., 1978 for hydrothermal alteration). The sequence of interstratified I-S minerals with different I/S ratios also includes a continuous change in the ordering of layer-stacking from smectite-rich R0 I-S to illite-rich R3 I-S, where R is the Reichweite parameter (Jagodzinski, 1949). However, recent transmission electron microscopy (TEM) studies indicated that smectite, R1 and illite layers are abundant, whereas I-S with other types of orderings (i.e., R>1) are rare (Dong et al, 1997; Bauluz et al., 2000 and references therein). Thus the continuous change in proportion of S- and I-layers and the orderings indicated by XRD investigations is in contradiction with the discontinuous change revealed by TEM observations.

Altaner and Ylagan (1997) and Plançon (2004) argued that there are two ways to describe the layer-stacking sequence of I-S interstratification from the crystallochemical points of view. That is, one is the interstratification of two individual 2:1 layers with respectively homogeneous smectite and illite compositions. This type of stacking model is called as a non-polar 2:1 layer model (Altaner and Ylagan, 1997). The other way is to describe it on the basis of stacking of two interlayer-centered smectite and illite in which each 2:1 layer has heterogeneous composition, and it is called as a polar 2:1 layer model (Altaner and Ylagan, 1997). It is still controversial which is the better way to describe the layer stacking sequence of I and S layers within a crystallite which acts as a coherent unit able to scatter X-rays. Furthermore, whether or not the third component layer, which is often called "vermiculite" or "high-charged smectite" 
layer, exists in I-S stacks and whether or not the formation acts as an essential step during smectite illitization are unresolved (e.g., Drits et al., 1997a; Meunier et al., 2000). Finally, since the illitization mechanism is deduced from these basic XRD and TEM data, the mechanistic relations between layer-by-layer, solid-state transformation (SST) and dissolution-crystallization (DC) models are major points of contention (Altaner and Ylagan, 1997).

Both the illitization process and the crystal chemistry of I-S depend on variables in different systems, which include temperature, compositions of fluid and rock and water/rock ratio in addition to geologic time. Among many geologic environments mentioned above, hydrothermal alteration is the most appropriate to investigate illitization because we can minimize the effects of precursor materials on illitization in hydrothermally altered volcanic rocks. Although the illitization in diagenesis of pelitic rocks is most common, the rocks contain precursor smectite, detrital illite and other phyllosilicates. Variability in the inherited characteristics of smectite formed in preceding weathering may influence on succeeding illitization during burial diagenesis. The factor of time may be ignored in the case of I-S formation in hydrothermal alteration because the formation generally took place over a geologically short period of time in contrast to burial diagenesis.

This study investigates an I-S series of hydrothermal alteration origin, i.e., I-S minerals from a drill hole (IT-2) near the Kakkonda active geothermal system, Japan. This field is characterized by constant, high geothermal gradients $\left(15^{\circ} \sim 20^{\circ} \mathrm{C} / 100 \mathrm{~m}\right)$ at least up to $1700 \mathrm{~m}$, neither boiling nor circulation of fluids, and no alteration overprint (Inoue et al., 2001). The I-S minerals are formed from Miocene to Pleistocene felsic volcaniclastic rocks with a limited range of composition under temperatures similar to the present temperature and nearly constant water/rock ratio (Inoue et al., 2001; 2004). The occurrence, bulk mineralogy, fluid geochemistry and isotope characteristics were described in detail in these previous papers. More detailed XRD and high-resolution TEM (HRTEM) characterization of selected I-S minerals has been undertaken to elucidate the unresolved points mentioned above and to better understand the mechanism of I-S formation. This work consists of two parts; special attention in the first part is paid to characterize the expandability behavior of component layers in the Kakkonda I-S series based on one-dimensional XRD structure analysis and 
supplementary examinations by alkylammonium ions exchange and Li ion saturation techniques. The results of HRTEM study will be described in part 2 (Murakami et al., 2005 , this issue).

\section{SAMPLES AND EXPERIMENTAL METHODS}

Samples

Eleven samples were selected from an I-S series in felsic volcaniclastic rocks from a drill core (Hole IT-2) near the Kakkonda active geothermal system, Japan. A summary of sample characteristics is provided in Table 1.

X-Ray diffraction structure analysis

Structure analysis of seven samples $(435 \mathrm{~m}, 580 \mathrm{~m}, 635 \mathrm{~m}, 645 \mathrm{~m}, 690 \mathrm{~m}, 700 \mathrm{~m}$ and $756 \mathrm{~m}$ ) was carried out using Ca-saturated specimens to minimize the hydration heterogeneity of expandable interlayers. Separated clay fractions $(<2 \mu \mathrm{m})$ were first saturated with $\mathrm{Ca}$ ion and then the homoionic exchanged specimens were $\mathrm{X}$-rayed in two states, air-dried (at controlled relative humidity of 40\%) and ethylene glycolated (saturated with ethylene glycol (EG) atmosphere at $70^{\circ} \mathrm{C}$ overnight). XRD patterns were recorded using a Bruker D5000 diffractometer equipped with a Kevex Si (Li) solid-state detector and $\mathrm{Cu} \mathrm{K \alpha}$ radiation. Intensities were recorded at a $0.04^{\circ} 2 \theta$ interval, from $2-50^{\circ}$, using $6 \mathrm{sec}$ counting time per step.

A program developed by Drits et al. (1997a) and Sakharov et al. (1999) was used to fit experimental XRD profiles. Many parameters necessary for simulating XRD profiles were set as done by Claret et al. (2004). We assumed the existence of three component layers, illite (I), smectite (S) and vermiculite (V) composed of each non-polar 2:1 layer in the simulations. The S-layer is defined as a fully expandable interlayer with $2 \mathrm{H}_{2} \mathrm{O}$ molecules at $40 \%$ relative humidity or $2 \mathrm{EG}$ molecules when the interlayer site is occupied by homoionic Ca ions. The V-layer is defined as a partly expandable interlayer with $1 \mathrm{H}_{2} \mathrm{O}$ or $1 \mathrm{EG}$ molecules and the I-layer as a non-expandable interlayer without $\mathrm{H}_{2} \mathrm{O}$ or EG molecules (Drits et al., 1997a; Meunier et al., 2000). The amount and position of interlayer species such as $\mathrm{H}_{2} \mathrm{O}$ and $\mathrm{EG}$ molecules in addition to fixed $\mathrm{K}$ ion were considered as variable parameters during fitting process. 
The iron contents of octahedral sheets were also optimized during fitting. The accuracy of profile fitting was assessed by means of the residual factor $\left(\mathrm{R}_{\mathrm{WP}}\right)$ between experimental and simulated intensities at $2-50^{\circ} 2 \theta$ (Howard and Preston, 1989).

Alkylammonium exchange

Expandability (or layer charge) characteristics of component layers in I-S were also examined using two $\mathrm{C}_{12}$-alkylammonium (dodecylammonium) and $\mathrm{C}_{18}$-alkylammonium (octadecylammonium) exchanged specimens. Following the protocol described by Wilson (1987), about $15 \mathrm{~mL}$ of $\mathrm{pH}$-adjusted alkylammonium chloride solution ( $0.1 \mathrm{M}$ for $\mathrm{C}_{12}$-alkylammonium and $0.05 \mathrm{M}$ for $\mathrm{C}_{18}$-alkylammonium) were added to about $20 \mathrm{mg}$ of Na-saturated, freeze-dried powder specimens and heated in an oil bath at $65^{\circ} \mathrm{C}$ for three days. Excess alkylammonium chloride was removed by repeated washing with 1:1 ethanol/water and pure ethanol followed by centrifugation; the paste was spread over a glass slide and kept in a vacuum desiccator. The reproducibility was checked by two mutually-independent experiments.

XRD patterns of alkylammonium (AL) exchanged specimens were recorded using a Rigaku RAD-IB diffractometer with monochromatized $\mathrm{Cu} \mathrm{K} \alpha$ radiation. Intensities were recorded at a $0.01^{\circ} 2 \theta$ interval, from $2-33^{\circ}$, using $4 \mathrm{sec}$ counting time per step. Peak decomposition was made on experimental XRD profiles of $\mathrm{C}_{12}$-AL exchanged specimens over $2-12^{\circ} 2 \theta$ using a DECOMPXR program developed by Lanson (1997).

For comparison, vermiculite (Palabora, South Africa), two rectorite samples (Goto and Ohara, Japan) and another I-S series (Shinzan, Japan) were examined. The average layer charge of the Palabora vermiculite is $0.83 / \mathrm{O}_{10}(\mathrm{OH})_{2}$ based on data of Inoue (1984). The Goto rectorite is the same material as that studied by Lagaly (1979), though our sample contains illite and pyrophyllite as impurities. The structure formula of Ohara rectorite is $\left(\mathrm{K}_{0.92} \mathrm{Na}_{0.10} \mathrm{Ca}_{0.23}\right)\left(\mathrm{Al}_{3.86} \mathrm{Fe}^{3+}{ }_{0.07} \mathrm{Mg}_{0.09} \mathrm{Ti}_{0.01}\right)\left(\mathrm{Si}_{6.52} \mathrm{Al}_{1.48}\right) \mathrm{O}_{20}(\mathrm{OH})_{4}$ (Y. Shinohara, unpublished data). The Shinzan I-S minerals are hydrothermal alteration products of Miocene volcaniclastic rocks, of which composition is similar to those of Kakkonda. The mineralogy of Shinzan I-S series has been described in Inoue et al. (1978), Inoue and Utada (1983) and Inoue et al. (1987). The XRD and TEM characteristics have also been reported in many studies (e.g., Keller et al., 1986; Inoue 
et al., 1990 for XRD; Veblen et al., 1990; Amouric and Olives, 1991; Olives et al., 2000 for TEM). Thus the Shinzan I-S samples may be regarded as "a reference" of hydrothermal I-S minerals.

\section{Li-saturation}

Distinction between montmorillonitic and beidellitic components in smectite layers was made by Li-saturation (Hofmann and Klemen, 1950). Li-saturated specimen, using a normal $\mathrm{LiCl}$ solution, was heated at $300^{\circ} \mathrm{C}$ overnight in a ceramic crucible to avoid alkali-contamination from glass, then dispersed on a glass slide with water and glycerol-saturated after air-drying. The proportion of beidellitic component was estimated from comparison of experimental intensity ratios of 1.8-nm and 0.96-nm peaks with those of simulated XRD patterns assuming a segregation structure of beidellite and montmorillonite layers.

\section{RESULTS}

Interstratified structure analysis

Comparison of experimental and calculated XRD profiles at air-dried and EG-saturated states is illustrated in Figures 1 6, excluding the 580-m sample. The major structure parameters optimized by fittings are summarized in Table 2. For instance, in the 3-component layers system, the interstratified structure with $\mathrm{R}=1$ can be described by 9 junction probability parameters (e.g., $\mathrm{P}_{\mathrm{SS}}, \mathrm{P}_{\mathrm{SV}}, \mathrm{P}_{\mathrm{VS}}, \mathrm{P}_{\mathrm{VV}}$, and so on, where $\mathrm{P}_{\mathrm{SS}}$ denotes a junction probability of a $\mathrm{S}$ layer following a $\mathrm{S}$ layer) in addition to 3 parameters $\left(\mathrm{W}_{\mathrm{I}}, \mathrm{W}_{\mathrm{S}}\right.$ and $\left.\mathrm{W}_{\mathrm{V}}\right)$ of the proportion (or occurrence probability) of each component. Only essential parameters are listed in Table 2, and all the other parameters can be easily calculated from those given in the table (Watanabe, 1988; Drits and Tchoubar, 1990). The optimized $\mathrm{d}_{001}$ value of I-layer was $0.998 \mathrm{~nm}$ for all the samples, those of S-layer were $1.52 \mathrm{~nm}$ at air-dried and $1.68 \mathrm{~nm}$ at EG-saturated, and those of V-layer varied from 1.23 1.25 nm at air-dried and from 1.29 1.40 nm at EG-saturated (Table 2). The $\mathrm{K}$ content of illite interlayer shows minimal variation and is 1.5-1.7/ $\mathrm{O}_{20}(\mathrm{OH})_{4}$ in all samples. The optimized Fe contents are consistent with the electron microprobe analyses (Table 1), except for the 435-m sample. The samples 
studied contain small amounts of impurities as given in Table 1. We did not subtract the contribution of impurities from original XRD profiles, and thereby the resultant $\mathrm{R}_{\mathrm{WP}}$ values became apparently large from $8.9 \%$ to $28.2 \%$. Nevertheless, taking into account agreement in terms of the peak positions and intensities of I-S minerals between the experimental and calculated XRD profiles in both the air-dried and EG-saturated samples, goodness of the fittings is satisfactory as seen in Figures 1 6.

Two samples, $435-\mathrm{m}$ and $580-\mathrm{m}$ are smectite containing $\sim 10 \%$ in total of I- and V-layers (Figure 1 and Table 2). Assuming $1.40 \mathrm{~nm}$ for the $\mathrm{d}_{001}$ value of vermiculite layer gave a better fitting for EG-saturated 580-m sample, though the value was greater than the other assumed value of $1.29 \mathrm{~nm}$ (Table 2). The reason of difference in d value is unknown. The optimized Fe content in the octahedral sheets in sample $435-\mathrm{m}$ is noticeably greater than that of the previous chemical analysis (Table 1). Inoue et al. (2004) reported that I-S mineral coexists with siderite at $435 \mathrm{~m}$. The difference in Fe content may be due to the contamination of siderite in microprobe-analyzed sample, whereas the major impurities of the sample used in the present XRD study are cristobalite and quartz. Calculating the occurrence probabilities of layer doublets, triplets and quartets from the junction probabilities and the proportions of component layers indicates that the SS doublet is mostly dominant within crystallites of 435-m and 580-m samples (Table 3). The occurrence probabilities of SIS and VIV triplets range around $0.02-0.04$ in the $435-\mathrm{m}$ and $0-0.02$ in the $580-\mathrm{m}$. The mean number of layers $(\mathrm{N})$ consisting of X-ray coherent domains is 10 for $435-\mathrm{m}$ and 7 for $580-\mathrm{m}$.

Sample 635-m (Figure 2) is an I-S mixed-layer mineral with $\mathrm{R}=0, \mathrm{~W}_{\mathrm{I}}=0.35$, $\mathrm{W}_{\mathrm{S}}=0.65$ at EG-saturation. The proportion of V-layer $\left(\mathrm{W}_{\mathrm{V}}\right)$ was estimated to be 0.1 at air-dried state but it was negligible at EG-saturation. In general, the $\mathrm{W}_{\mathrm{V}}$ value tended to be equal at EG-solvated and air-dried states in the most samples studied. In some samples, the $\mathrm{W}_{\mathrm{V}}$ value at EG-solvated was smaller than air-dried state (Table 2). But the reason was not specified in the present study. In 635-m sample, the I-layer percentage $(\% \mathrm{I})$ or $\mathrm{W}_{\mathrm{I}}$ value determined by the present $\mathrm{XRD}$ analysis was underestimated in the order of about $10 \%$ compared to that determined previously by a convenient saddle/peak ratio technique of Inoue et al. (1989) as shown in Table 1. The occurrence probability of an IS doublet $\left(\mathrm{W}_{\mathrm{IS}}\right)$ and SIS triplet $\left(\mathrm{W}_{\mathrm{SIS}}\right)$ increases to be $0.23\left(=\mathrm{W}_{\mathrm{I}} \cdot \mathrm{W}_{\mathrm{S}}\right)$ and $0.15\left(=\mathrm{W}_{\mathrm{S}} \cdot \mathrm{W}_{\mathrm{I}} \cdot \mathrm{W}_{\mathrm{S}}\right)$ respectively, whereas that of SS doublet decreases to be 0.42 
(Table 3) compared to those of the 435-m and 580-m samples. The mean number of layers is 15 at air-dried and 10 at EG-saturated state.

Sample 645-m (Figure 3) is a mixture of R0 and R1 ordered structures, of which proportions are $80 \%$ and $20 \%$ respectively (Table 2 ). The $\mathrm{W}_{\mathrm{V}}$ value in $\mathrm{R} 0$ phase was estimated to be 0.1 , but that in R1 phase was negligible at EG-saturation. For the R0 phase, it is noted that the occurrence probability of II doublet increases and that of SS doublet decreases, compared to those of the 635-m sample. For the R1 phase, the occurrence probabilities of II and SS doublets decrease, while those of IS doublet and SIS triplet increase remarkably (Table 3). The estimated mean number of layer is smaller in R1 phase than in R0 phase (Table 2). This relation is distinct at air-dried, but becomes ambiguous at EG-saturated state as the mean number of layers is 8 for the R0 phase and 7 for the R1 phase.

Sample 690-m (Figure 4) is a R1 ordered structure with $\mathrm{W}_{\mathrm{I}}=0.55, \mathrm{~W}_{\mathrm{S}}=0.4$, $\mathrm{W}_{\mathrm{V}}=0.05$ at EG-saturation. The occurrence probabilities of $\mathrm{W}_{\mathrm{IS}}\left(=\mathrm{W}_{\mathrm{I}} \cdot \mathrm{P}_{\mathrm{IS}}\right), \mathrm{W}_{\mathrm{IV}}$ $\left(=\mathrm{W}_{\mathrm{I}} \cdot \mathrm{P}_{\mathrm{IV}}\right)$ and $\mathrm{W}_{\mathrm{II}}\left(=\mathrm{W}_{\mathrm{I}} \cdot \mathrm{P}_{\mathrm{II}}\right)$ were calculated to be $0.32,0.03$ and 0.20 respectively (Table 3). Comparing to the R1 phase in 645-m sample, the occurrence probabilities of IS doublet and SIS triplet decrease and those of II doublet, IIS triplet and IIIS quartet increase. The mean number of layers is 15 at air-dried and EG-saturated states.

Structures of samples 700-m and 756-m (Figures 5 and 6) were determined to be $\mathrm{R} 2$ and $\mathrm{R} 3$ ordered structures respectively, assuming the arrangements of layers with maximum possible degree of ordering (MPDO) (Drits and Tchoubar, 1990). The proportion of V-layer is negligible in the two samples. In sample 700-m, the conditions of $\mathrm{R} 2$ ordering with $\mathrm{R} 1 \mathrm{MPDO}, \mathrm{W}_{\mathrm{I}}=0.6, \mathrm{~W}_{\mathrm{S}}=0.4$ at EG-saturation lead to $\mathrm{P}_{\mathrm{SS}}=0$ and result in $\mathrm{W}_{\mathrm{IS}}\left(=\mathrm{W}_{\mathrm{I}} \cdot \mathrm{P}_{\mathrm{IS}}\right)=0.40, \mathrm{~W}_{\mathrm{II}}\left(=\mathrm{W}_{\mathrm{I}} \cdot \mathrm{P}_{\mathrm{II}}\right)=0.20$ and $\mathrm{W}_{\mathrm{SIS}}\left(=\mathrm{W}_{\mathrm{S}} \cdot \mathrm{P}_{\mathrm{SI}} \cdot \mathrm{P}_{\mathrm{SIS}}\right)=0.10$. The occurrence probability of SIIS quartet $\left(=\mathrm{W}_{\mathrm{S}} \cdot \mathrm{P}_{\mathrm{SI}} \cdot \mathrm{P}_{\mathrm{SII}} \cdot \mathrm{P}_{\mathrm{IIS}}\right)$ is 0.11 in the $700-\mathrm{m}$ sample (Table 3). The \% I of 756-m sample was underestimated in the order of $10 \%$ compared to the previous estimate (Table 1), probably due to different types of interlayer cations in specimens used in the two XRD measurements. In the 756-m sample, $\mathrm{W}_{\mathrm{IS}}=0.13, \mathrm{~W}_{\mathrm{II}}=0.70$ and $\mathrm{W}_{\mathrm{IV}}=0.03$. The occurrence probabilities of III triplet and IIII quartet are extremely large compared to the other samples. The mean number of layers is 10 for $700-\mathrm{m}$ sample and 20 for $756-\mathrm{m}$ sample. 
Alkylammonium exchange

XRD profiles of Kakkonda I-S series treated with $\mathrm{C}_{12}$ - and $\mathrm{C}_{18}-\mathrm{AL}$ are illustrated in Figure 7. For comparison, XRD profiles of vermiculite and rectorite are given in Figure 8. The basal spacing of smectite increased from $1.38 \mathrm{~nm}$ of $214-\mathrm{m}$ to $1.72 \mathrm{~nm}$ of $580-\mathrm{m}$ for $\mathrm{C}_{12}$-AL exchanged samples and from $1.77 \mathrm{~nm}$ of $214-\mathrm{m}$ to $1.9 \mathrm{~nm}$ of 580-m for $\mathrm{C}_{18}$-AL exchanged samples. The XRD peaks of AL-exchanged smectite appear to be single and symmetric, suggesting a relatively homogeneous charge distribution. The change in basal spacing corresponds to the monolayer or bilayer arrangement of alkylammonium molecules due to increasing the mean layer charge (Lagaly, 1994). Extremely small $\mathrm{d}_{001}$ values (1.38 $\mathrm{nm}$ by $\mathrm{C}_{12}-\mathrm{AL}$ exchange and $1.77 \mathrm{~nm}$ by $\mathrm{C}_{18}$-AL exchange) of 214-m sample are caused by the low-charged interlayer (Inoue et al., 2004). Excluding the 214-m sample, the mean values of layer charge tend to increase with increasing depth or the formation temperature, but the extent of the increase is extremely small. The mean layer charge of expandable interlayer in Kakkonda smectite ranges within $0.3 \sim 0.4 / \mathrm{O}_{10}(\mathrm{OH})_{2}$, when the values were evaluated using the calibration curves of Olis et al. (1990). The Palabora vermiculite exhibited symmetric, rational series reflections of $2.3 \mathrm{~nm}$ by $\mathrm{C}_{12}$-AL exchange and $3.1 \mathrm{~nm}$ by $\mathrm{C}_{18}$-AL exchange (Figure 8). The basal spacing of the Palabora vermiculite is brought about by a paraffin type of arrangement of alkylammonium ions (see the definition of Lagaly, 1994) in high-charge interlayer with $>0.75 / \mathrm{O}_{10}(\mathrm{OH})_{2}$ according to Olis et al. (1990). Although the XRD structure analysis recognized the V-layer of at maximum 9\% at air-dried state in the 435-m and 580-m samples (Table 2), a discrete vermiculite phase was not detected by the AL-treatments.

The 635-m sample has a R0, 35\% I structure by the present structure analysis. A major peak at $1.8 \mathrm{~nm}$ is associated with a broad shoulder around $2.3 \mathrm{~nm}$ by $\mathrm{C}_{12}-\mathrm{AL}$ exchange, while the two peaks shifted to $3.7 \mathrm{~nm}$ by $\mathrm{C}_{18}$-AL exchange (Figure 7). Peak decomposition of the $\mathrm{C}_{12}$-AL exchanged sample gives two peaks at 1.8 and $2.0 \mathrm{~nm}$ (Figure 10). The 656-m sample with R1, $60 \%$ I (Table 1) showed a 3.0-nm reflection for the $\mathrm{C}_{12}$-AL exchanged sample associated with the nearly rational higher order reflections. The $\mathrm{C}_{18}$-AL exchanged, 656-m sample showed a set of integral reflections of $3.3 \mathrm{~nm}(001), 1.65 \mathrm{~nm}(002)$ and $1.07 \mathrm{~nm}(003)$. The expandability behavior is similar to those of true rectorite samples from Goto and Ohara (Figure 8 and Lagaly, 
1979), though the reflections of 656-m sample become broader and greater in d value than true rectorite. I-S samples with $>$ R3, $>85 \%$ I (756-m and 919-m) showed a discrete peak around $1 \mathrm{~nm}$ in addition to peaks at $2.45 \mathrm{~nm}$ and $\sim 1.2 \mathrm{~nm}$ by $\mathrm{C}_{12}$-AL exchange. The 2.45-nm peak is similar to that appeared in the 635-m sample. The I-S samples with $>\mathrm{R} 1,>60 \%$ I displayed a basal spacing of 3.3 3.6 $\mathrm{nm}$ and the rational higher order reflections by $\mathrm{C}_{18}$-AL exchange, which is similar to the behavior of the $635-\mathrm{m}$ sample but not similar to macroscopic vermiculite.

The Shinzan I-S series exhibited similar expandability behavior for $\mathrm{C}_{12}$-AL exchange (Figure 9) and $\mathrm{C}_{18}$-AL exchange (not presented) as functions of \% I and Reichweite parameters to those of Kakkonda series mentioned above. Extra peaks by $\mathrm{C}_{12}$-AL exchange appeared at low-angle side of the main peak of about $1.8 \mathrm{~nm}$ in all $\mathrm{R} 0$ samples from Shinzan. Peak decomposition of the Shinzan R0 and R1 phases, together with the Kakkonda I-S minerals, indicates that the position of extra peaks shifts gradually toward the $\mathrm{d}_{001}(2.8 \sim 3.0 \mathrm{~nm})$ of R1 structure with increasing \% I (Figure 10).

\section{Li-saturation}

In the Li-saturation test, the layer charge arising from octahedral substitution in montmorillonite is neutralized by migration of Li ions at heating, whereas the charge arising from tetrahedral substitution in beidellite is not neutralized by the Li-migration. As a result, 1.8-nm and 0.96-nm peaks after glycerol-solvation are representative of beidellitic and montmorillonitic layers, respectively (Wilson, 1987). The result of the Li-saturation tests (Figure 11) indicates that the proportion of beidellite component increases from $\sim 0.1$ of the $320-\mathrm{m}$ to 0.55 of the $580-\mathrm{m}$ samples and the $214-\mathrm{m}$ sample contains about 0.2 of beidellite component, which is consistent with the chemical analysis data (Table 1).

\section{DISCUSSION}

Characteristics of component layers in I-S

The one-dimensional XRD analysis of interstratification revealed that the Kakkonda I-S minerals are composed of three component (S, V and I) layers with variable proportions. Actually the V-layer content is very low through the I-S series. 
The optimized $\mathrm{d}_{001}$ value of I-layer is $0.998 \mathrm{~nm}$ and is similar to those for diagenetic I-S samples reported by Drits et al. (1997a) and Claret et al. (2004). Drits et al. (1997b) indicated that the $\mathrm{d}_{001}$ value of I-layer increases when the interlayer is occupied partly by $\mathrm{NH}_{4}$ ions. The $\mathrm{NH}_{4}$ ion was not detected in the Kakkonda I-S samples by preliminary FTIR measurements (not presented). The K content of I-layer is invariable around $0.75 \mathrm{~K} / \mathrm{O}_{10}(\mathrm{OH})_{2}$ regardless of $\% \mathrm{I}$. The $\mathrm{K}$ content is smaller than that of the hypothetical end member illite $\sim 0.9 \mathrm{~K} / \mathrm{O}_{10}(\mathrm{OH})_{2}$, which is extrapolated from a plot of fixed $\mathrm{K}$ content versus \% I using bulk chemical analyses of I-S minerals from various origins (Meunier and Velde, 1989; Lanson and Champion, 1991; Srodon et al., 1992). Particles of more illitic I-S samples (e.g., 756-m and 919-m samples) show a lath-shaped morphology (Inoue et al., 2004). In general, the K content of illite is smaller in lath-shaped than in hexagonal ones (Meunier and Velde, 2004). The fixed K content of illitic interlayer in I-S, as well as that in the end member illite of smectite illitization, may warrant further discussion.

As for the response to alkylammonium exchange, the impurity illite present in the Goto rectorite sample did not expand with $\mathrm{C}_{12}-\mathrm{AL}$ exchange. It is known that micaceous illites react very slowly with alkylammonium ions (Lagaly, 1994). If the illitic interlayer in I-S is non-expandable with $\mathrm{C}_{12}$-AL exchange, sub-units of several I-layers such as III triplets and IIII quartets may behave as a segregated domain of illite present within a crystallite of I-S. This is related to the expandability behavior observed in $\mathrm{C}_{12}$-AL exchanged, 756-m and 919-m samples (Figure 7). However, the illitic interlayer expands partly by $\mathrm{C}_{18}-\mathrm{AL}$ exchange, and thus the $\mathrm{C}_{18}$-AL exchange is inappropriate for the characterization of expandability of component layers in I-S minerals.

The S-layer in the Ca-saturated Kakkonda I-S samples showed a constant expandability of $1.68 \mathrm{~nm}$ at EG solvation and $1.52 \mathrm{~nm}$ at air-dried (Table 2). They also showed constant behavior for AL-exchange so as to reflect the respective mean layer charges of $0.3 \sim 0.4 / \mathrm{O}_{10}(\mathrm{OH})_{2}$. As described previously, on the other hand, two peaks at $1.8 \mathrm{~nm}$ and 2.0 2.3 nm were observed in R0 I-S minerals (e.g., 635-m sample) by $\mathrm{C}_{12}$-AL exchange as well as in the Shinzan R0 I-S minerals (Figures 7 and 10). If the sample is a stack of layers with a homogeneous layer charge, the 1.8-nm value of major peak can be explainable either by the transition of monolayer to bilayer or by that of 
bilayer to pseudotrimolecular layer; the estimated layer charge is 0.38 or $0.47 / \mathrm{O}_{10}(\mathrm{OH})_{2}$ respectively according to Olis et al. (1990). The layer charge values are within those $\left(<0.5 / \mathrm{O}_{10}(\mathrm{OH})_{2}\right)$ of fully expandable S-interlayer based on the data of Christidis and Eberl (2003). The second peak of 2.0 2.3 nm by $\mathrm{C}_{12}$-AL exchange corresponds to a range of layer charge from $0.56 \sim 0.71 / \mathrm{O}_{10}(\mathrm{OH})_{2}$, assuming the transition of bilayer to pseudotrimolecular layer. The layer charge is classified into that of high charge smectite (Chiristidis and Eberl, 2003) or vermiculite. The above assignment of $\mathrm{C}_{12}-\mathrm{AL}$ exchanged XRD peaks is inconsistent with the previous XRD results in which the $635-\mathrm{m}$ sample consists of $35 \%$ of I-layer and $65 \%$ of S-layer. The I-layer has $0.75 \mathrm{~K} / \mathrm{O}_{10}(\mathrm{OH})_{2}$ and a non-expandable interlayer with $\mathrm{C}_{12}-\mathrm{AL}$ exchange. Thus it is more likely that the $2.0 \sim 2.3 \mathrm{~nm}$ peak appearing by $\mathrm{C}_{12}$-AL exchange may be derived from random interstratification of IS doublets and S-layers within the crystallites. A rough estimation for the $635-\mathrm{m}$ sample predicts a peak generated from the random interstratification of IS and SS doublets to appear around $2.2 \mathrm{~nm}(=(0.23 / 0.23+0.42) \mathrm{x}$ $2.8 \mathrm{~nm}+(0.42 / 0.23+0.42) \times 1.8 \mathrm{~nm})$, assuming that the $\mathrm{d}_{001}$ value of an IS doublet is $2.8 \mathrm{~nm}(=1.0 \mathrm{~nm}+1.8 \mathrm{~nm})$, that of S-layer is $1.8 \mathrm{~nm}, \mathrm{~W}_{\mathrm{IS}}=0.23$ and $\mathrm{W}_{\mathrm{SS}}=0.42$. This value is close to the observed one. As shown in Figure 10, the extra peak by $\mathrm{C}_{12}-\mathrm{AL}$ exchange shifts toward larger $d$ values with increasing \% I, in other words, with increasing the proportion of IS doublet. This fact supports the above interpretation. The major 1.8-nm peak by $\mathrm{C}_{12}$-AL exchange is interpreted to be derived from the dominant smectitic interlayers.

The $\%$ I of $656-\mathrm{m} \mathrm{I-S} \mathrm{with} \mathrm{R}=1$, of which $\%$ I was estimated to be $62 \%$ by Inoue et al. (2004), is somewhat larger than $50 \%$ of perfectly ordered rectorite (i.e., Goto and Ohara samples). The 656-m sample contains much more II doublets and IIS triplets in crystallites compared to perfectly R1-ordered rectorite, inferring from the XRD data of the 690-m sample and the R1 phase in the 645-m sample (Table 3). This results in deviation of peak position by $\mathrm{C}_{12}$ - $\mathrm{AL}$ exchang from that of true rectorite, as shown by Lagaly (1979). The expandability behavior of $>$ R3 I-S phases (e.g., 756-m and 919-m samples) by $\mathrm{C}_{12}$-AL exchange cannot be explained by the assumption of vermiculite layer because of their negligible amounts by EG-saturation. Rather, the expanbability behavior may be interpreted by random interstratification of several types of multiplets organized by abundant I-layers and few S-layers. In conclusion there is 
considerable variability in the response in expandability of the component layers in I-S depending on the used reagents and the variability leads to ambiguity in the interpretation. We cannot obtain more accurate structural information on the AL-exchanged I-S minerals because the detailed arrangement of intercalated AL ions in the interlayer sites is unknown. Nevertheless, it is emphasized that the $\mathrm{C}_{12}$-AL exchange data, in combination with the structure data by usual $\mathrm{H}_{2} \mathrm{O}$ - and $\mathrm{EG}$-saturation, provide useful information on the stacking sequence of component layers in I-S crystallites as discussed below.

The Li-saturation test of Kakkonda smectite and R0 I-S reveals that the expandability behavior of smectitic interlayer is independent of the content of beidellitic layer at least up to 0.5 .

\section{Layer stacking model of I-S}

As mentioned previously, there are two models to describe the component layers constituted the I-S interstratification: non-polar and polar 2:1 layer models (Altaner and Ylagan, 1997). Plançon (2004) demonstrated that there is not noticeable difference in simulated XRD patterns between the two models, unless the charge of 2:1 layer is derived from the Si-Fe substitutions in tetrahedral sheets. This suggests that the structure parameters obtained in the present study may be applied to either the polar 2:1 layer model or the non-polar 2:1 layer model, though the latter model was used actually in the simulation. Previous NMR investigation of rectorite supports the polar layer model (Barron et al., 1985; Altaner et al., 1988; Jakobsen et al., 1995). A first-principles calculation of Stixrude and Peacor (2002) demonstrated that the polar 2:1 layer structure has a total energy lower than the non-polar structure for rectorite. Lagaly (1979) explained the expandability behavior of alkylammonium-exchanged rectorite on the polar layer model scheme. In contrast to the polar layer model, in theory, three types of interlayer sites are expected within a crystallite of I-S with 2-component layers in the non-polar layer model: a low-charge interlayer behaved as smectite, a high-charge interlayer as illite and an intermediate-charge interlayer as "vermiculite", because the interstratification is composed of chemically homogeneous smectite and illite layers that are electrically neutral in each layer (Plançon, 2004). In fact, only negligible amounts of vermiculite layer were detected in the present XRD analysis of Kakkonda I-S minerals 
using the non-polar 2:1 layer model. Consequently, the interpretation of layer stacking in I-S minerals should be constructed consistently on the basis of the polar 2:1 layer model scheme regardless of \% I values.

For the intention of describing the mode of layer stacking, we introduce a new symbol M, which is different from the Reichweite parameter. Following the polar layer model, and taking into account the occurrence probabilities of layer doublets, triplets and quartets (Table 3) and the expandability behavior by AL-exchange, an I-S crystallite stacked by several layers can be considered to consist of several types of sub-units (or modules) such as M0 (-SS-), M1 (-SIS-), M2 (-SIIS-), M3 (-SIIIS-), ..... Mn (-SI.....IS-), where the S and I stand for the smectitic and illitic interlayers on the basis of the polar 2:1 layer model. The -S and S- represent a half part of smectitic interlayer at the outermost surface and the $n$ denotes the number of illitic interlayers sandwiched between two outermost smectitic surfaces. A similar model was applied to the interpretation of TEM images of I-S minerals by Bauluz et al. (2000). This module-stacking model may be useful to interpret the XRD patterns of alkylammonium-exchanged I-S minerals as discussed above, as well as the HRTEM images (Murakami et al., 2005, this issue). Since the ordering of I-S minerals (i.e., Reichweite) represents long-range ordering averaged over all layers that scatter X-ray radiation, direct application of the module-stacking model to XRD data may be inappropriate at present. Nevertheless we infer that for example, the occurrence probability of an IS doublet or a SIS triplet is related to that of M1 (-SIS-) type of module within an I-S crystallite. The actual modes of layer stacking will be provided by the HRTEM observations of the AL-exchanged samples (Murakami et al., 2005 this issue).

Transformation of I-S minerals

The Kakkonda I-S minerals studied here are constituents of sequential smectite illitization in hydrothermally alterated volcanic rocks as a function of temperature from $70^{\circ} \mathrm{C}$ to $200^{\circ} \mathrm{C}$ (Inoue et al., 2004). According to the present module-stacking model, the illitization can be described as follows. The smectite precipitated at temperatures of $<140^{\circ} \mathrm{C}$ from solution through hydrolysis reactions of volcanic glass with meteoric water. This interpretation is supported by the textural observations and oxygen isotope 
measurements (Inoue et al., 2004). The precipitate is a stack of M0 type of module. The mean layer charges of product smectite (or M0 modules) are $0.3 \sim 0.4 / \mathrm{O}_{10}(\mathrm{OH})_{2}$. The V-layer contents are in the order of $10 \%$ at maximum. The I-layer contents also are very low but occurs as a M1 type of module in the crystallites with $\mathrm{N}<10$. Since it is assumed that the composition of original volcanic rocks and the water/rock ratio during the illitization are nearly constant at Kakkonda (Inoue et al., 2004), the precipitation of modules is a function of temperature and fluid composition.

There are few occurrences of R0 I-S minerals in the studied drill hole (Inoue et al., 2004). With increasing temperature only slightly to $154^{\circ} \mathrm{C}$, a R0 I-S mineral with $35 \%$ I formed at $635 \mathrm{~m}$ depth. The mode of layer stacking in the 635-m R0 I-S sample may be described as a mixing of M0 and M1 units. The mean layer charge of smectitic interlayer increases slightly to $0.38 \sim 0.47 / \mathrm{O}_{10}(\mathrm{OH})_{2}$ but the $\mathrm{K}$ content of illitic interlayer is constant at $0.75 / \mathrm{O}_{10}(\mathrm{OH})_{2}$. An I-S mineral with $\mathrm{R} 1$ ordering, $\sim 60 \% \mathrm{I}$ formed at $656 \mathrm{~m}$ $\left(158^{\circ} \mathrm{C}\right)$ via the occurrence of a two-phase mixture of $\mathrm{R} 0$ and $\mathrm{R} 1$ structures at $645 \mathrm{~m}$ depth. The $656-\mathrm{m} \mathrm{I-S} \mathrm{mineral} \mathrm{may} \mathrm{be} \mathrm{characterized} \mathrm{by} \mathrm{a} \mathrm{mixing} \mathrm{of} \mathrm{dominant} \mathrm{M1}$ modules and small amounts of $>\mathrm{M} 2$ modules, and negligible amount of M0 module, inferring from the data of 690-m sample. With further increasing depth and temperature, $\mathrm{R} 2$ phase formed at $700 \mathrm{~m}\left(166^{\circ} \mathrm{C}\right)$ and $\mathrm{R} 3$ phase at $756 \mathrm{~m}\left(175^{\circ} \mathrm{C}\right)$. The $756-\mathrm{m}$ sample with R3, 85\% I is characterized by a mixing of dominant $>\mathrm{M} 2$ sub-units with non-expandable illite domains. It does not contain M0 modules, and the amount of M1 module is negligible. The $\mathrm{K}$ ion content in illitic interlayer of precipitating $\mathrm{Mn}(\mathrm{n} \geqq 1)$ modules is constant at $0.75 / \mathrm{O}_{10}(\mathrm{OH})_{2}$ at $70-175^{\circ} \mathrm{C}$. The above transformation is described by a stepwise precipitation of various types of modules as a function of temperature, which is compared with the consecutive change in the Reichweite from R0, $\mathrm{R} 1, \mathrm{R} 2$ to R3. On the other hand, a model of stepwise smectite illitization process was inferred from the TEM investigation of both diagenetic and hydrothermal I-S samples (Dong et al., 1997; Bauluz et al., 2000; Masuda et al., 2001; Tillick et al., 2001; Yan et al., 2001; Bauluz et al., 2002). In their model, the transformation of smectite illitization is characterized by discontinuity from smectite $\rightarrow \mathrm{R} 1 \mathrm{I}-\mathrm{S} \rightarrow$ illite without $\mathrm{R} 0, \mathrm{R} 2$, and R3 I-S, using the Reichweite parameter.

In another point of view, Drits et al. (1997a) noted from XRD study of pelitic rocks from North Sea that the proportion of V-layer remained constant at levels of $\mathrm{W}_{\mathrm{V}}=$ 
0.04-0.08 in the latest stage of illitization. They proposed a single interlayer transformation (SIT) mechanism via K-fixation in vermiculitic interlayer and succeeding transformation to illitic interlayer, which is equivalent to a layer-by-layer SST mechanism. In the Kakkonda I-S series, the V-layer content was very small as a whole and rather tended to decrease at latest stage of illitization (Table 2). The 700-m sample has a R2 ordering, of which phase was considered to be relatively rare in smectite illitization (Inoue and Utada, 1983; Srodon and Eberl, 1984). It is expected that illitization by layer-by-layer SST mechanism produces R3 structure directly from R1 structure without via R2 structure (Drits, 1997). Thus the layer-by-layer transformation model via the formation of vermiculite layers is difficult to apply to the smectite illitization mechanism in hydrothermal alteration of volcanic rocks at Kakkonda. The transformation mechanism from R1 to R3 will be discussed in more detail based on the module-stacking model in part 2 (Murakami et al., 2005, this issue).

\section{SUMMARY AND CONCLUSIONS}

In this study, we determined the one-dimensional layer stacking sequence of I-S including the quantification of occurrence probabilities of several types of layer-doublets, layer-triplets and layer-quartets, using an I-S series from hydrothermally altered volcanic rocks. Supplementary alkylammonium exchange and Li- saturation experiments, together with the above XRD data, provided information on the expandability and stacking characteristics of the component layers in I-S minerals. The results led to the following conclusions,

(1) The XRD analysis indicated that the smectite illitization in the Kakkonda I-S minerals series occurred with a consecutive change in the $\mathrm{R}$ parameter from $\mathrm{R} 0$ to $\mathrm{R} 3$ in the temperature range of $70-175^{\circ} \mathrm{C}$.

(2) Some of the I-S minerals contained $<10 \%$ vermiculite layer as the third component, but the content was small as a whole and tended to decrease with progressive illitization.

(3) The interlayer $\mathrm{K}$ content of illite layer was almost constant at $1.5-1.7 / \mathrm{O}_{20}(\mathrm{OH})_{4}$ through the illitization.

(4) The $\mathrm{C}_{12}$-alkylammonium exchange experiments indicated that the layer stacking of 
R0-type I-S minerals is composed of IS subunits and S layers, rather than individual I and $\mathrm{S}$ layers. The I layers within $\geq \mathrm{R} 3$ I-S crystallites behaved as segregated domains for the $\mathrm{C}_{12}$-alkylammonium exchange.

(5) The expandability behavior of smectite and R0 I-S is independent of the content of beidellitic layer at least up to 0.5 .

Consequently, the layer stacking in I-S crystallites is consistently interpreted by introducing a new model in which the I-S crystallites consist of component modules such as M0, M1, ..., Mn based on the polar 2:1 layer. The smectite illitization occurs with the appearance and disappearance of such modules as a function of temperature in hydrothermally altered volcanic rocks, but not by a layer-by-layer mechanism via K-fixation in vermiculite layer. But it is apparent that the XRD results alone cannot assess the proposed model, and it must be ascertained by different methods such as TEM investigation.

\section{ACKNOWLEDGMENTS}

We are grateful to V. A. Drits for his help to simulate XRD patterns and Y. Shinohara for his providing Ohara rectorite with unpublished chemical analysis data. This manuscript was greatly improved by the comments of H. Dong, M. Krekeler, and D. McCarty. A part of the experimental works was carried out during a short stay in Poitiers University and A. Inoue is grateful to CNRS, France for providing the opportunity. B. Sakharov would acknowledge financial support from CNRS "poste rouge" for his stay in Grenoble. This work was partly supported by the Science Grant of the Ministry of Education, Science and Culture in Japan.

\section{REFERENCES}

Altaner, S. P. and Ylagan, R. F. (1997) Comparison of structural models of mixed-layer illite/smectite and reaction mechanisms of smectite illitization. Clays and Clay Minerals, 45, 517-533.

Altaner, S. P., Weiss, C. A. Jr. and Kirkpatrick, R. J. (1988) Evidence from ${ }^{29}$ Si NMR for the structure of mixed-layer illite/smectite clay minerals. Nature, 331, 
699-702.

Amouric, M. and Olives, J. (1991) Illitization of smectite as seen by high-resolution transmission electron microscopy. European Journal of Mineralogy, 3, 831-835.

Barron, R. F., Slade, P. and Frost, R. L. (1985) Ordering of aluminium in tetrahedral sites in mixed-layer 2:1 phyllosilicates by solid-state high-resolution NMR. Journal of Physical Chemistry, 89, 3880-3885.

Bauluz, B., Peacor, D. R. and Gonzalez Lopez, J. M. (2000) Transmission electron microscopy study of illitization in pelites from the Iberian Range, Spain: layer-by-layer replacement? Clays and Clay Minerals, 48, 374-384.

Bauluz, B., Peacor, D. R. and Ylagan, R. F. (2002) Transmission electron microscopy study of smectite illitization during hydrothermal alteration of a rhyolitic hyaloclastite from Ponza, Italy. Clays and Clay Minerals, 50, 157-173.

Christidis, G. E. and Eberl, D. D. (2003) Determination of layer-charge characteristics of smectites. Clays and Clay Minerals, 51, 644-655.

Claret, F., Sakharov, B. A., Drits, V. A., Velde, B., Meunier, A., Griffault, L. and Lanson, B. (2004) Clay Minerals in the Meuse-Haute Marne underground laboratory (France): Possible influence of organic matter on clay mineral evolution. Clays and Clay Minerals, 52, 515-532.

Dong, H., Peacor, D. R. and Freed, R. L. (1997) Phase relations among smectite, R1 illite-smectite, and illite. American Mineralogist, 82, 379-391.

Drits, V. A. (1997) Mixed-layer minerals. Pp. 153-190 in: Modular Aspects of Minerals (S. Merlino, editor), EMU Notes in Mineralogy 1, Eötvös University Press., Budapest.

Drits, V. A. and Tchoubar, C. (1990) X-Ray Diffraction by Disordered Lamellar Structures. Springer-Verlag, Berlin, 371pp.

Drits, V. A., Lindgreen, H., Sakharov, B. A. and Salyn, A. S. (1997a) Sequence structure transformation of illite-smectite-vermiculite during diagenesis of Upper Jurassic shales, North Sea. Clay Minerals, 33, 351-371.

Drits, V. A., Lindgreen, H. and Salyn, A. L. (1997b) Determination of the content and distribution of fixed ammonium in illite-smectite by X-ray diffraction: Application to North Sea illite-smectite. American Mineralogist, 82, 79-87. 
Hofmann, U. and Klemen, R. (1950) Verlust der Austauschfahigeit von Lithiumionen an Bentonit durch Erhitzung. Zeitschrift fur Anorganische Chemie, 262, 95-99.

Howard, S. A. and Preston, K. D. (1989) Profile fitting of powder diffraction patterns. Pp. 217-275 in: Modern Powder Diffraction (D. L. Bish and J. E. Post, editors), Reviews in Mineralogy 20, Mineralogical Society of America, Washington, DC.

Hower, J., Eslinger, E. V., Hower, M. E. and Perry, E. A. (1976) Mechanism of burial metamorphism of argillaceous sediments: Mineralogical and chemical evidence. Geological Society of America Bulletin, 87, 725-737.

Inoue, A. (1984) Thermodynamic study of Na-K-Ca exchange reactions in vermiculite. Clays and Clay Minerals, 32, 311-319.

Inoue, A. and Utada, M. (1983) Further investigations of a conversion series of dioctahedral mica/smectites in the Shinzan hydrothermal alteration area, northeast Japan. Clays and Clay Minerals, 31, 401-412.

Inoue, A., Minato, H. and Utada, M. (1978) Mineralogical properties and occurrence of illite/montmorillonite mixed layer minerals formed from Miocene volcanic glass in Waga-Omono district. Clay Science, 5, 123-136.

Inoue, A., Kohyama, N., Kitagawa, R. and Watanabe, T. (1987) Chemical and morphological evidence for the conversion of smectite to illite. Clays and Clay Minerals, 35, 111-120.

Inoue, A., Bouchet, A., Velde, B. and Meunier, A. (1989) Convenient technique for estimating smectite layer percentage in randomly interstratified illite/smectite minerals. Clays and Clay Minerals, 37, 227-234.

Inoue, A., Watanabe, T., Kohyama, N. and Brusewitz, A. M. (1990) Characterization of illitization of smectite in bentonite beds at Kinnekulle, Sweden. Clays and Clay Minerals, 34, 241-249.

Inoue, A., Hara, J. and Imai, A. (2001) Genesis of Na-series rock alteration widespread in the southeastern area of Hachimantai geothermal field: water-rock interactions driven by descending groundwater and fossil seawater. Shigen-Chishitsu (Journal of Society of Resource Geology, Japan), 51, 101-120 (in Japanese).

Inoue, A., Meunier, A. and Beaufort, D. (2004) Illite-smectite mixed-layer minerals in 
felsic voclaniclastic rocks from drill cores, Kakkonda, Japan. Clays and Clay Minerals, 52, 66-84.

Jagodzinski, H. (1949) Eindimensionale fehlordnung in hristallen und ihr einfluss auf die Rontgeninterferenzen. I. Berechnung des fehlordnungsgrades au der Rontgenintensitaten. Acta crystallographica, 2, 201-207.

Jakobsen, H. J., Nielsen, N. C. and Lindgreen, H. (1995) Sequences of charged sheets in rectorite. American Mineralogist, 80, 247-252.

Keller, W. D., Reynolds, R. D., Jr. and Inoue, A. (1986) Morphology of clay minerals in the smectite-to-illite conversion series by scanning electron microscopy. Clays and Clay Minerals, 34, 187-197.

Lagaly, G. (1979) The "layer charge" of regular interstratified 2:1 clay minerals. Clays and Clay Minerals, 27, 1-10.

Lagaly, G. (1994) Layer charge determination by alkylammonium ions. Pp. 1-46 in: Layer Charge Characteristics of 2:1 Silicate Clay Minerals (A. R. Mermut, editor), Clay Mineral Society Workshop Lectures 6, The Clay Mineral Society.

Lanson, B. (1997) Decomposition of experimental X-ray diffraction patterns (profile fitting): a convenient way to study clay minerals. Clays and Clay Minerals, $\mathbf{4 5 ,}$ $132-146$.

Lanson, B. and Champion, D. (1991) The I/S-to-illite reaction in the late stage diagenesis. American Journal of Science, 291, 473-506.

Masuda, H., Peacor, D. R. and Dong, H. (2001) Transmission electron microscopy study of conversion of smectite to illite in mudstones of the Nankai Trough: Contrast with coeval bentonites. Clays and Clay Minerals, 49, 109-118.

Meunier, A. and Velde, B. (1989) Solid Solution in illite/smectite mixed layer minerals and illite. American Mineralogist, 74, 1106-1112.

Meunier, A. and Velde, B. (2004) Illite. Springer, Berlin, 286pp.

Meunier, A., Lanson, B. and Beaufort, D. (2000) Vermiculitization of smectite interfaces and illite layer growth as a possible dual model for illite-smectite illitization in diagenetic environments: a synthesis. Clay Minerals, $\mathbf{3 5}$, $573-586$.

Murakami, T., Inoue, A., Lanson, B., Meunier, A. and Beaufort, D. (2005) Illitesmectite mixed-layer minerals in hydrothermal alteration of volcanic rocks: II. 
One-dimensional HRTEM structure-images and formation mechanism. Clays and Clay Minerals (this issue).

Olis, A. C., Malla, P. B. and Douglas, L. A. (1990) The rapid estimation of the layer charges of 2:1 expanding clays from a single alkylammonium ion expansion. Clay Minerals, 25, 39-50.

Olives, J., Amouric, M. and Perbost, R. (2000) Mixed layering of illite-smectite: Results from high-resolution transmission electron microscopy and lattice-energy calculations. Clays and Clay Minerals, 48, 282-289.

Plançon, A. (2004) Consistent modeling of the XRD patterns of mixed-layer phyllosilicates. Clays and Clay Minerals, 52, 47-54.

Sakharov, B. A., Lindgreen, H., Salyn, A. and Drits, V. A. (1999) Determination of illite-smectite structures using multispecimen X-ray diffraction profile fitting. Clays and Clay Minerals, 47, 555-566.

Srodon, J. and Eberl, D. D. (1984) Illite. Pp. 495-544 in: Micas (S. W. Bailey, editor), Reviews in Mineralogy 13, Mineralogical Society of America, Washington DC.

Srodon, J., Elsass, F., MacHardy, W. J. and Morgan, D. J. (1992) Chemistry of illitesmectite inferred from TEM measurements of fundamental particles. Clay Minerals, 27, 137-158.

Tillick, D. A., Peacor, D. R. and Mauk, J. L. (2001) Genesis of dioctahedral phyllosilicates during hydrothermal alteration of volcanic rocks: I. The Golden Cross epithermal ore deposit, New Zealand. Clays and Clay Minerals, 49, 126-140.

Veblen, D. R., Guthrie, G. D., Livi, K. J. T. and Reynolds, R. C., Jr. (1990) Highresolution transmission electron microscopy and electron diffraction of mixed-layer illite/smectite: Experimental results. Clays and Clay Minerals, 38, $1-13$.

Watanabe, T. (1988) The structure model of illite/smectite interstratified mineral and the diagram for its identification. Clay Science, 7, 97-114.

Wilson, M. J. (1987) X-ray powder diffraction methods. Pp. 26-98 in: A Handbook of Determinative Methods in Clay Mineralogy (M. J. Wilson, editor), Blackie, Glasgow. 
Yan, Y., Tillick, D. A., Peacor, D. R. and Simmons, S. F. (2001) Genesis of dioctahedral phyllosilicates during hydrothermal alteration of volcanic rocks: II. The Broadlands-ohaaki hydrothermal system, New Zealand. Clays and Clay Minerals, 49, 141-155. 
Figure captions

Figure 1. Comparison of experimental (cross) and calculated (line) XRD patterns of 435-m sample at Ca-saturated, air-dried (a) and Ca-saturated, EG-saturated (b). crist: cristobalite. The vertical scales are different in two parts of $2-12^{\circ}$ and $12-50^{\circ} 2 \theta$. The numerical values stand for the $\mathrm{d}$ values in $\mathrm{nm}$ of experimental patterns.

Figure 2. Comparison of experimental (cross) and calculated (line) XRD patterns of 635-m sample at Ca-saturated, air-dried (a) and Ca-saturated, EG-saturated (b). qz: quartz, pl: plagioclase. The vertical scales are different in two parts of $2-12^{\circ}$ and $12-50^{\circ}$ $2 \theta$. The numerical values stand for the $d$ values in $n m$ of experimental patterns.

Figure 3. Comparison of experimental (cross) and calculated (line) XRD patterns of 645-m sample at Ca-saturated, air-dried (a) and Ca-saturated, EG-saturated (b). qz: quartz. The vertical scales are different in two parts of $2-12^{\circ}$ and $12-50^{\circ} 2 \theta$. The numerical values stand for the d values in nm of experimental patterns.

Figure 4. Comparison of experimental (cross) and calculated (line) XRD patterns of 690-m sample at Ca-saturated, air-dried (a) and Ca-saturated, EG-saturated (b). qz: quartz. The vertical scales are different in two parts of $2-12^{\circ}$ and $12-50^{\circ} 2 \theta$. The numerical values stand for the $\mathrm{d}$ values in $\mathrm{nm}$ of experimental patterns.

Figure 5. Comparison of experimental (cross) and calculated (line) XRD patterns of 700-m sample at Ca-saturated, air-dried (a) and Ca-saturated, EG-saturated (b). qz: quartz. The vertical scales are different in two parts of $2-12^{\circ}$ and $12-50^{\circ} 2 \theta$. The numerical values stand for the d values in nm of experimental patterns.

Figure 6. Comparison of experimental (cross) and calculated (line) XRD patterns of 756-m sample at Ca-saturated, air-dried (a) and Ca-saturated, EG-saturated (b). The vertical scales are different in two parts of $2-12^{\circ}$ and $12-50^{\circ} 2 \theta$. The numerical values stand for the $\mathrm{d}$ values in $\mathrm{nm}$ of experimental patterns. 
Figure 7. XRD traces of alkylammonium-exchanged specimens from Kakkonda I-S series. (a) dodecylammonium, (b) octadecylammonium, cor: corrensite.

Figure 8. XRD traces of alkylammonium-exchanged vermiculite and rectorite. Thin and thick lines correspond to XRD after dodecylammonium $\left(\mathrm{C}_{12}\right)$ and octadecylammonium $\left(\mathrm{C}_{18}\right)$ exchange, respectively.

Figure 9. XRD traces of $\mathrm{C}_{12}$-alkylammonium-exchanged I-S series from Shinzan. Reichweite (R) and \%I values were cited from Inoue et al. (1987). Ill: illite, chl: chlorite.

Figure 10. Decomposition of XRD patterns of $\mathrm{C}_{12}$-alkylammonium exchanged I-S minerals from Kakkonda and Shinzan. Each peak of the experimental curves (cross) after subtracting the background was decomposed by 1-4 peaks (thin curves) assuming a Gaussian shape.

Figure 11. XRD traces of Kakkonda I-S samples after Li-saturation test (Hofmann and Klemen, 1950). 

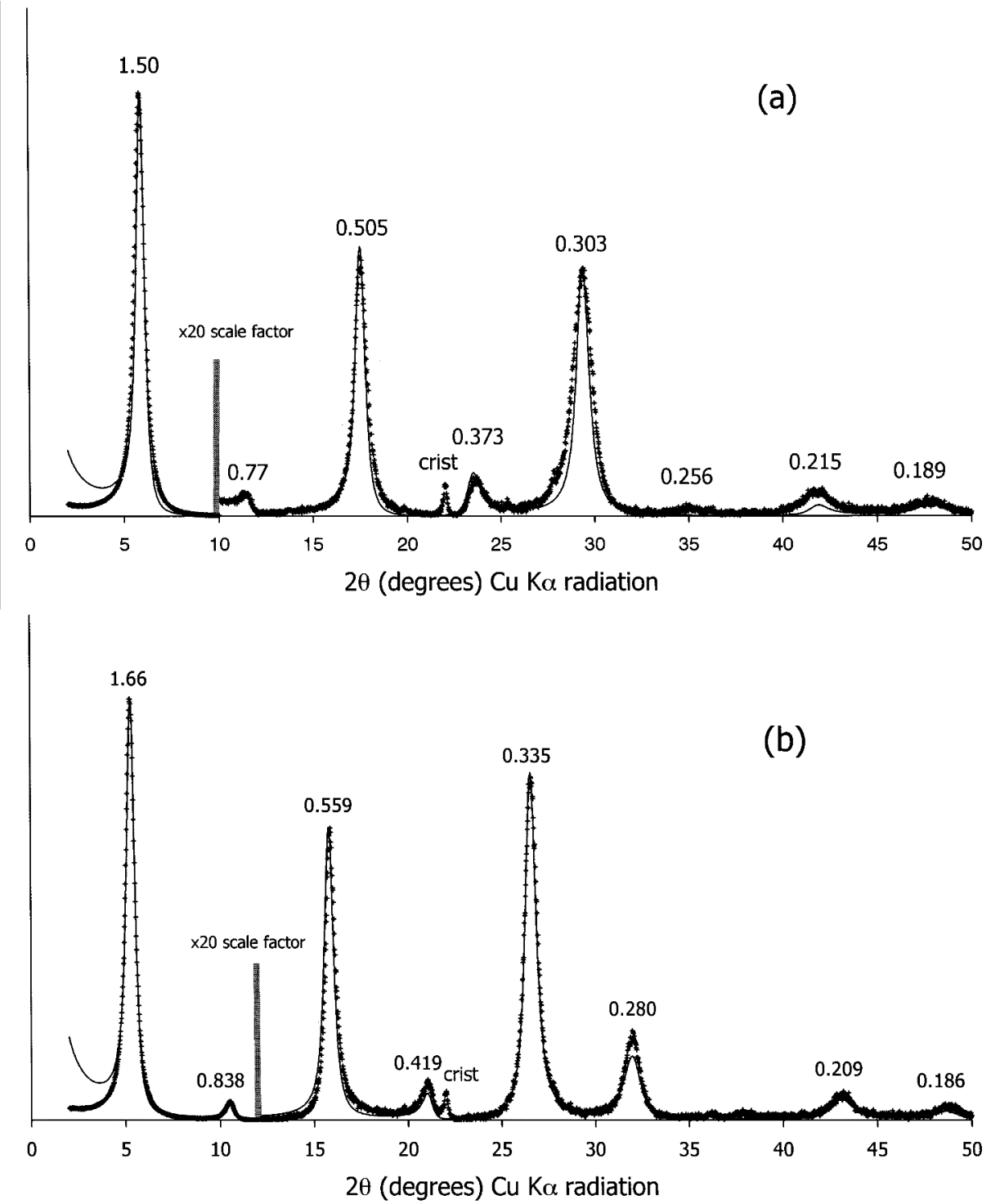

Figure 1 

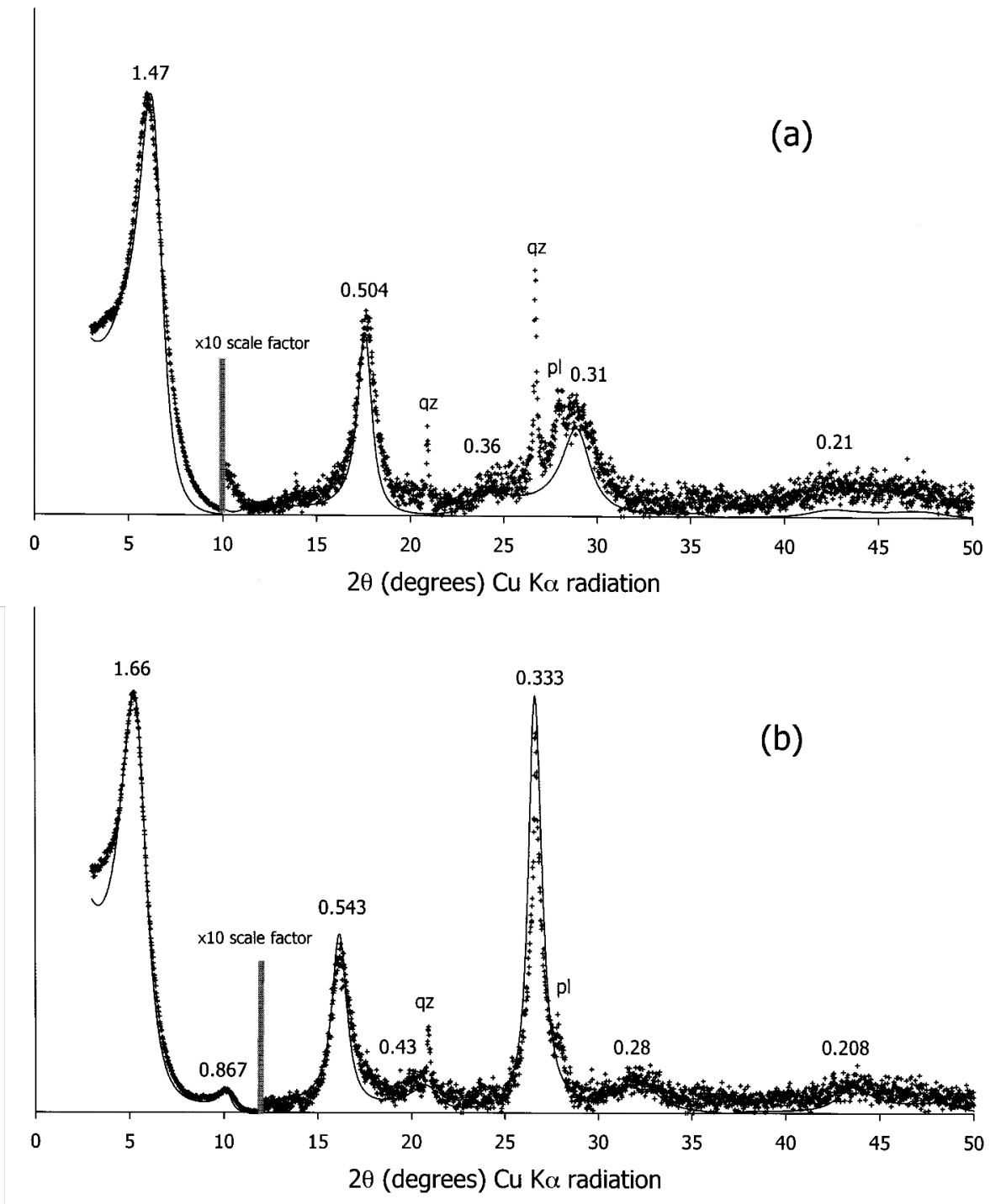

Figure 2 

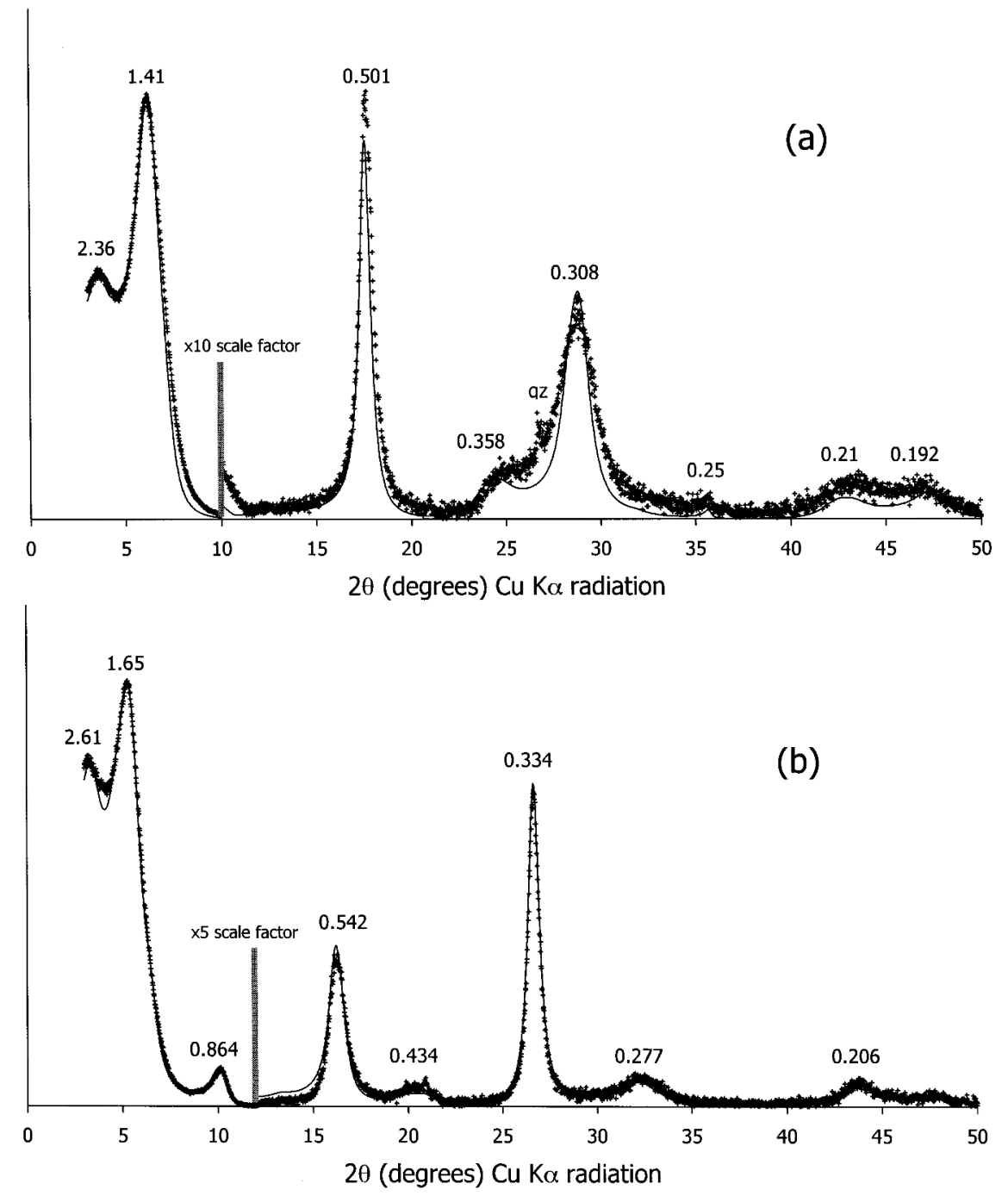

Figure 3 

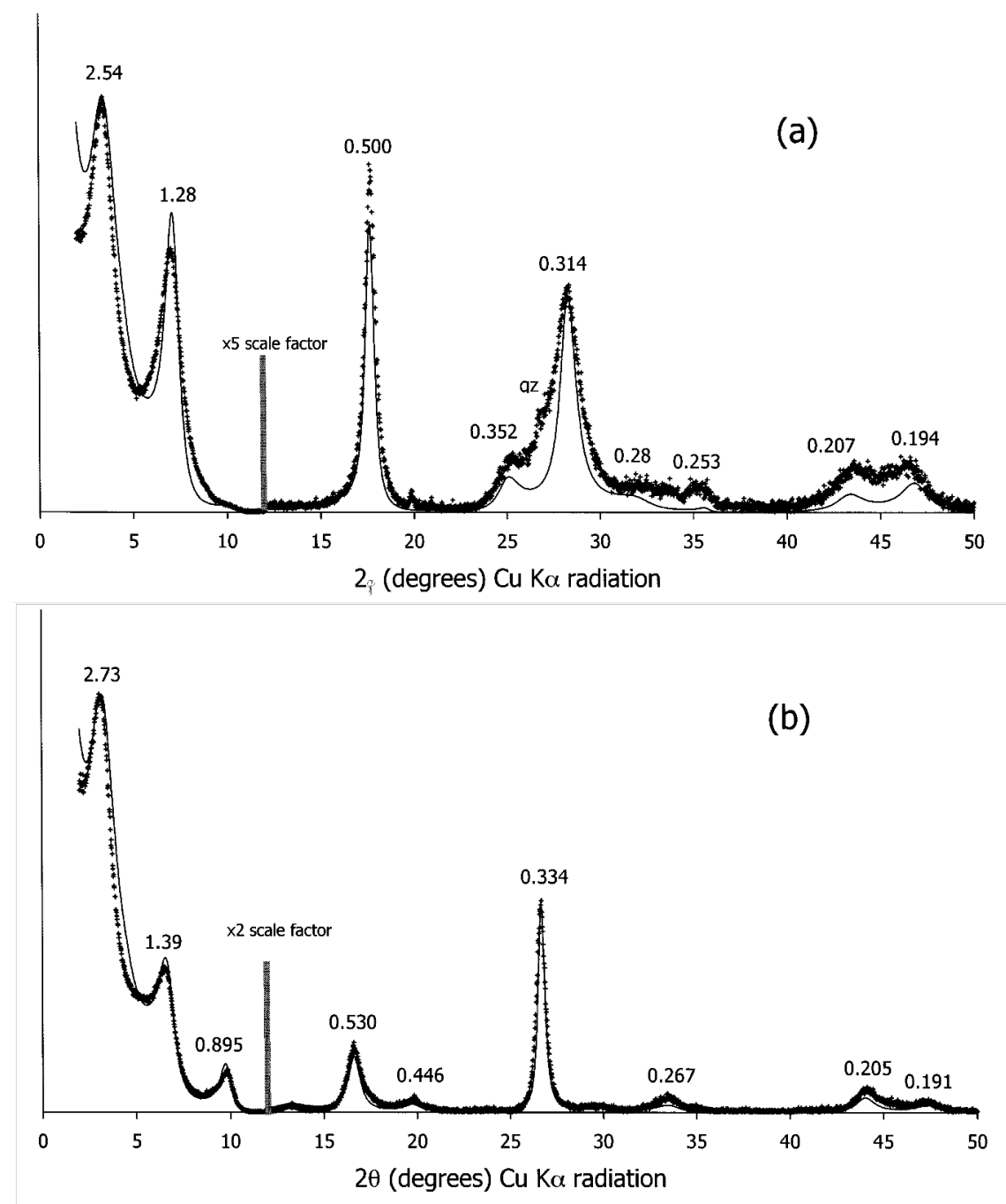

Figure 4 

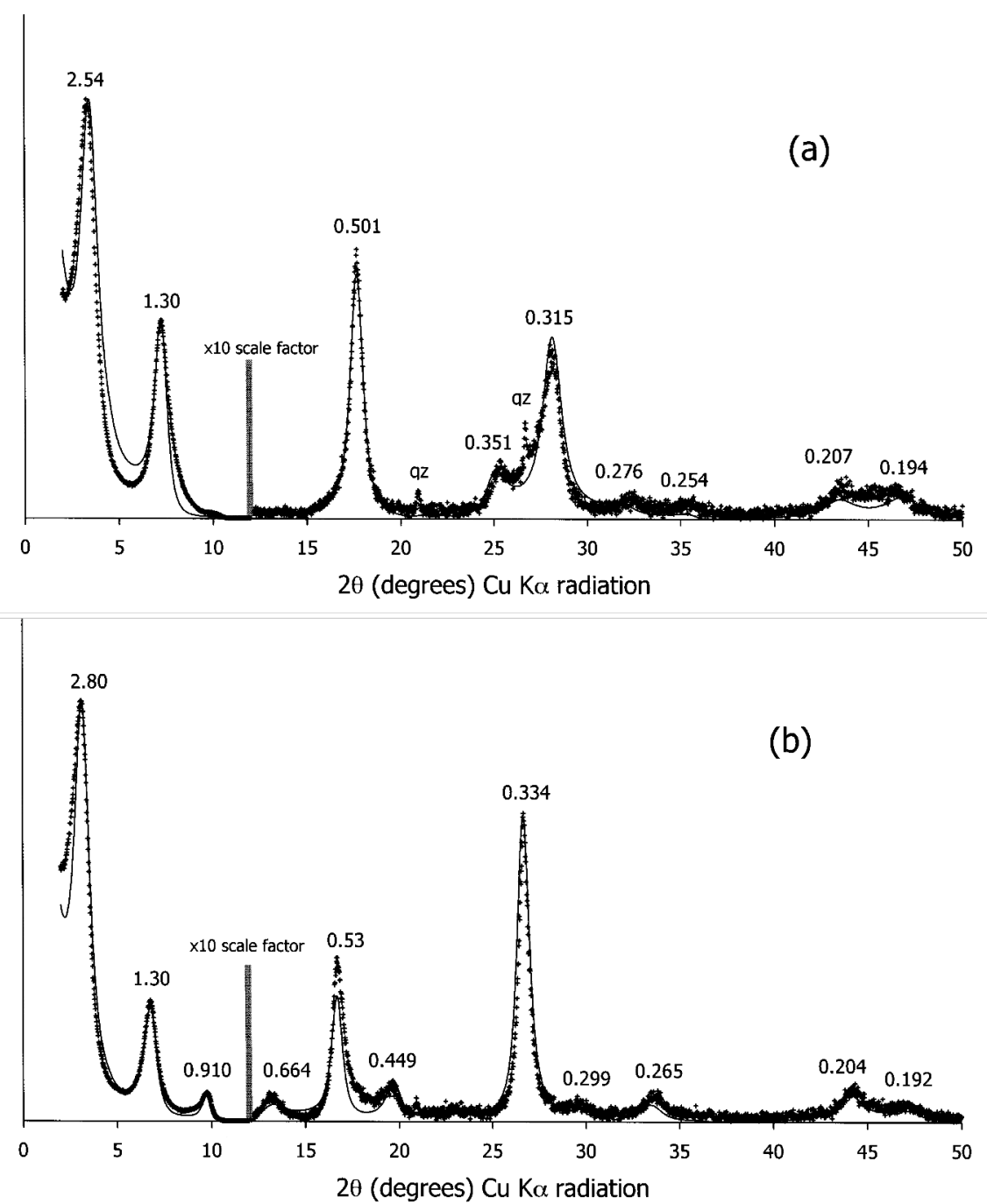

Figure 5 

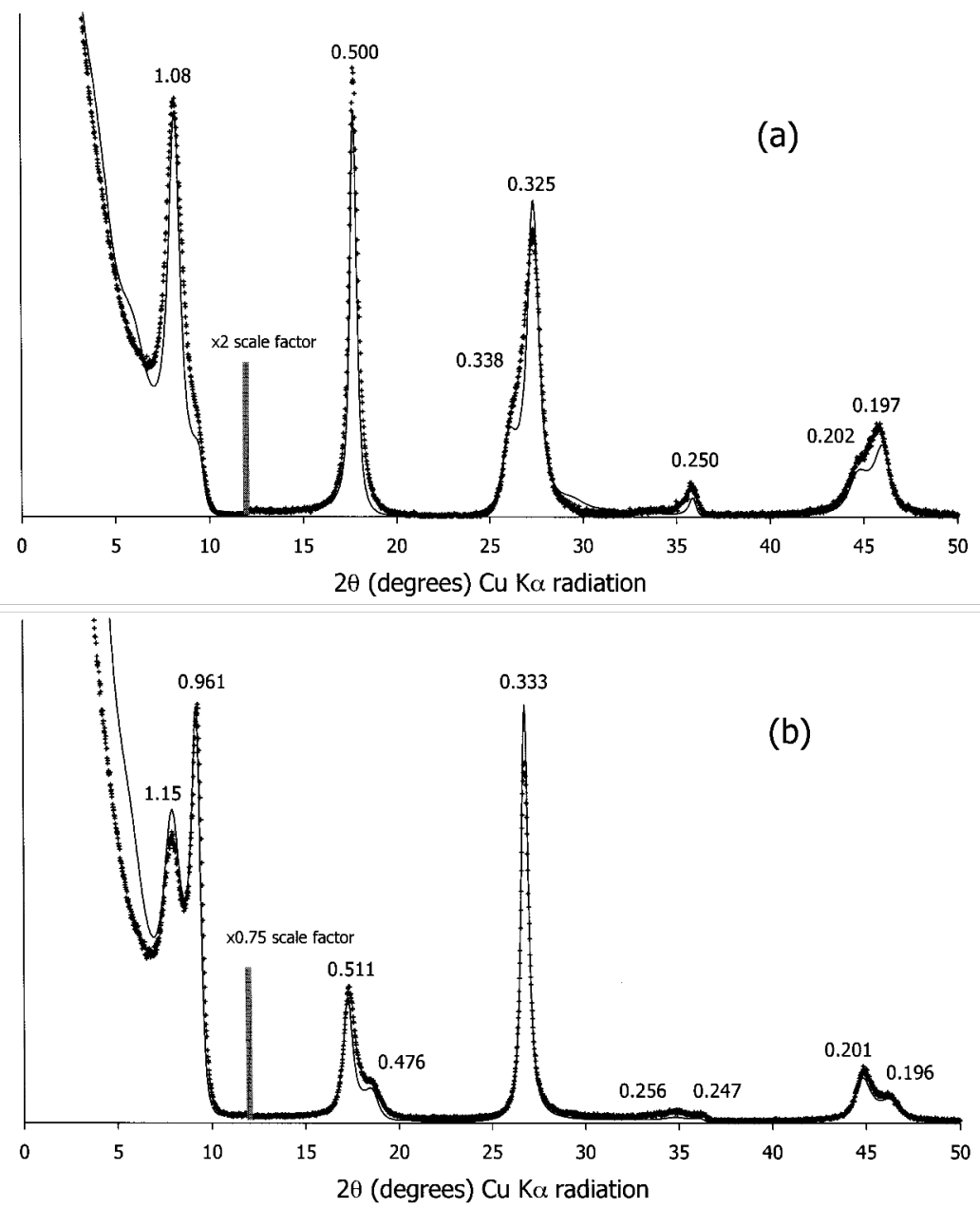

Figure 6 

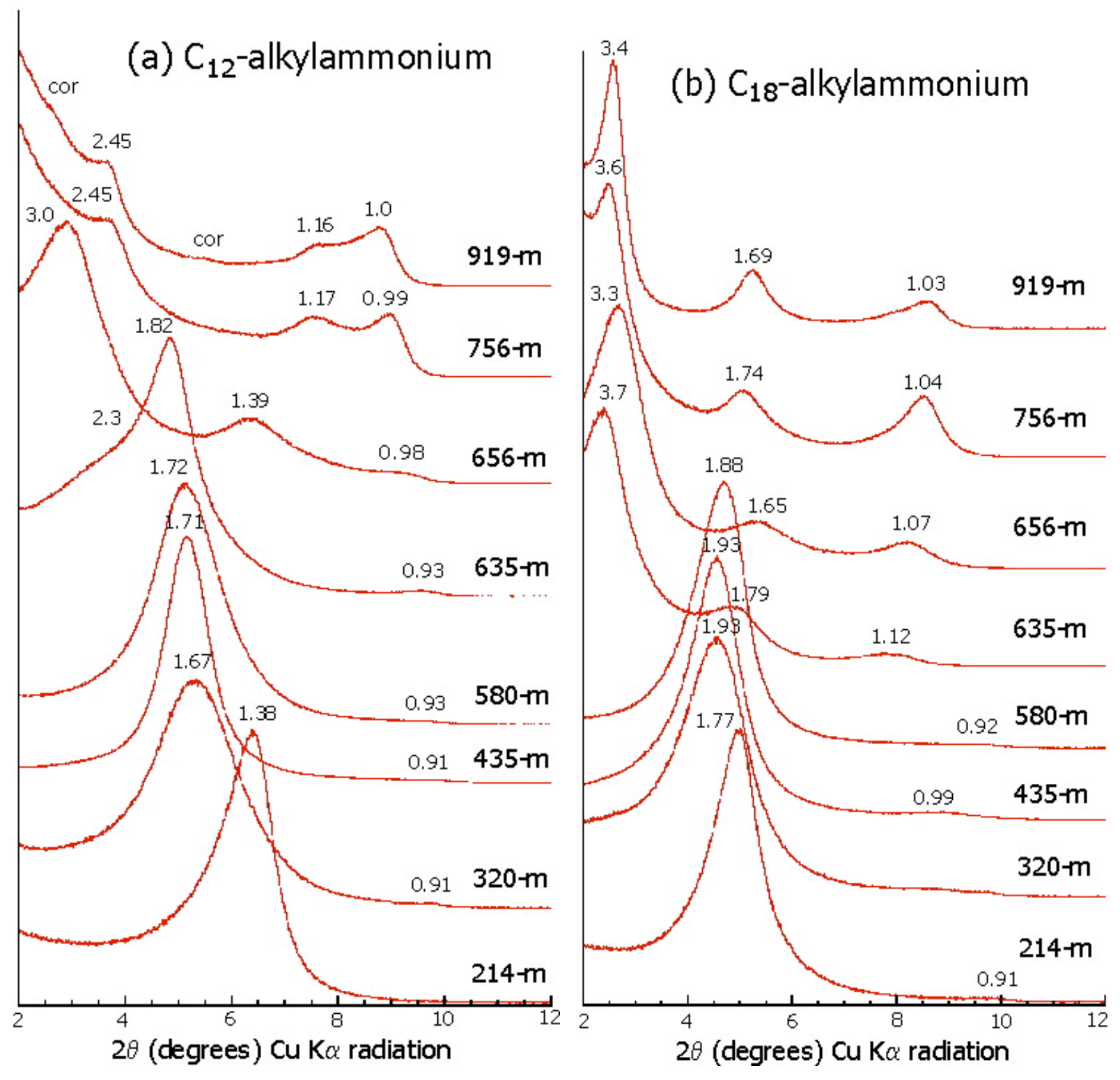

Figure 7 


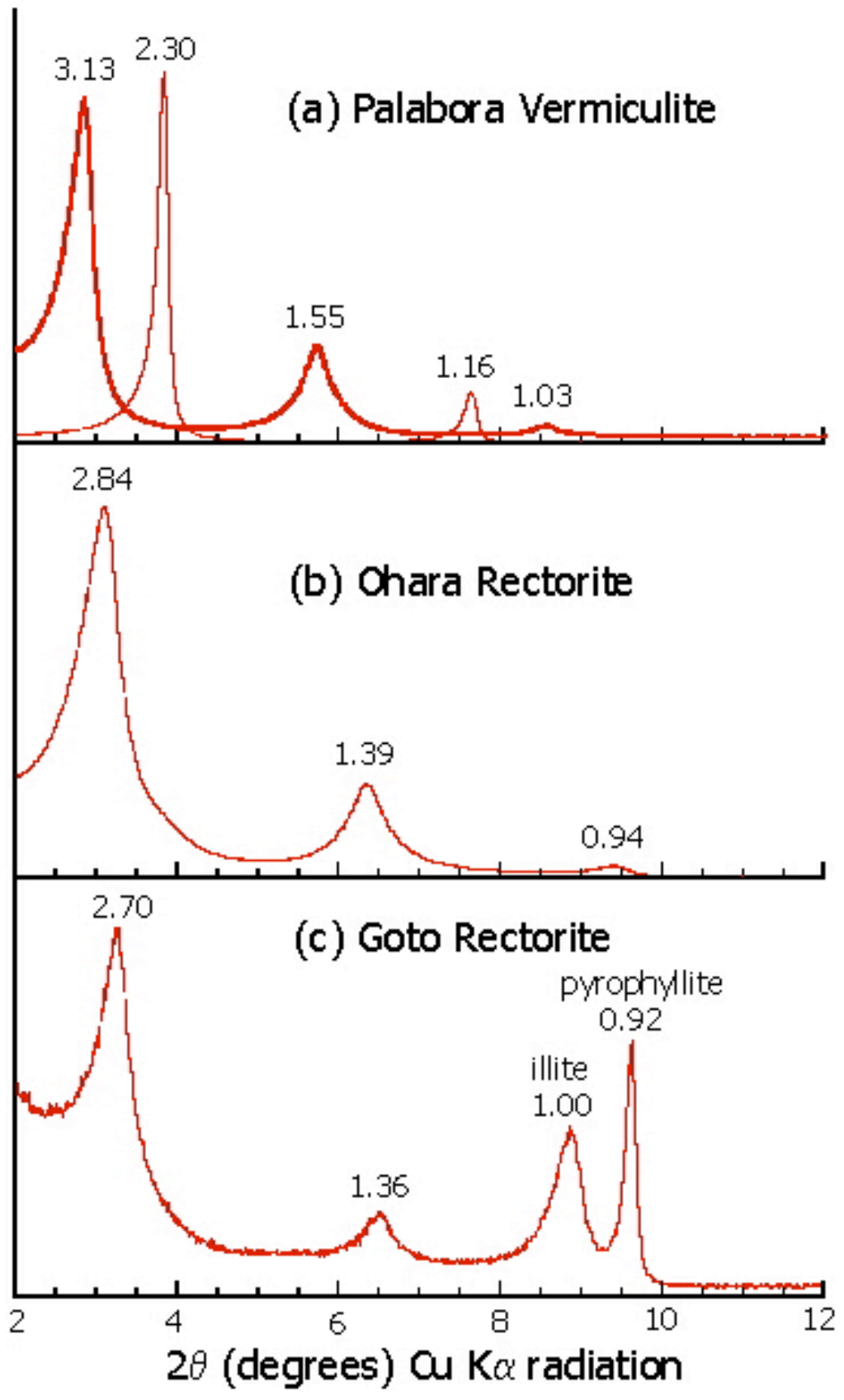

Figure 8 


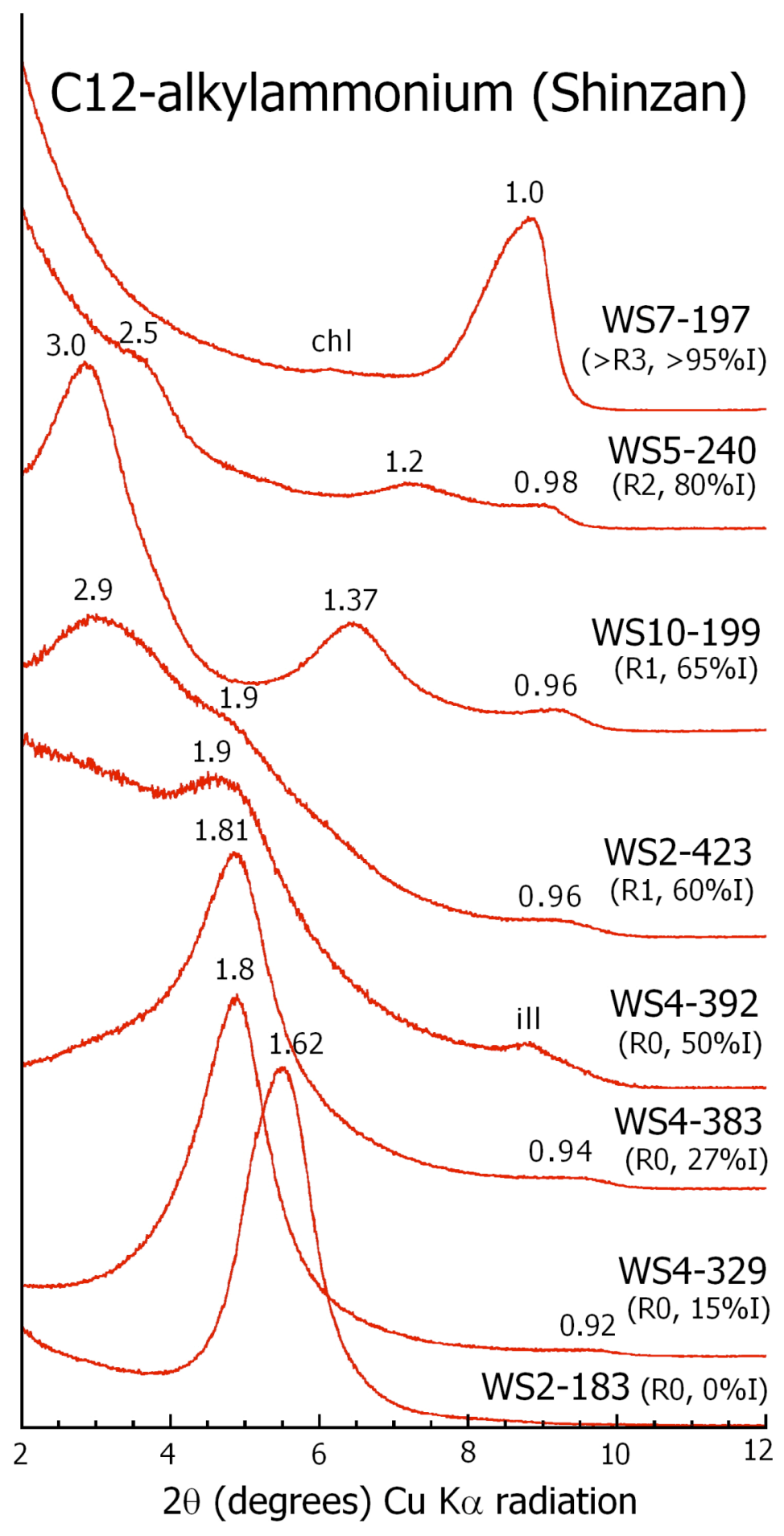

Figure 9 


\section{Kakkonda}
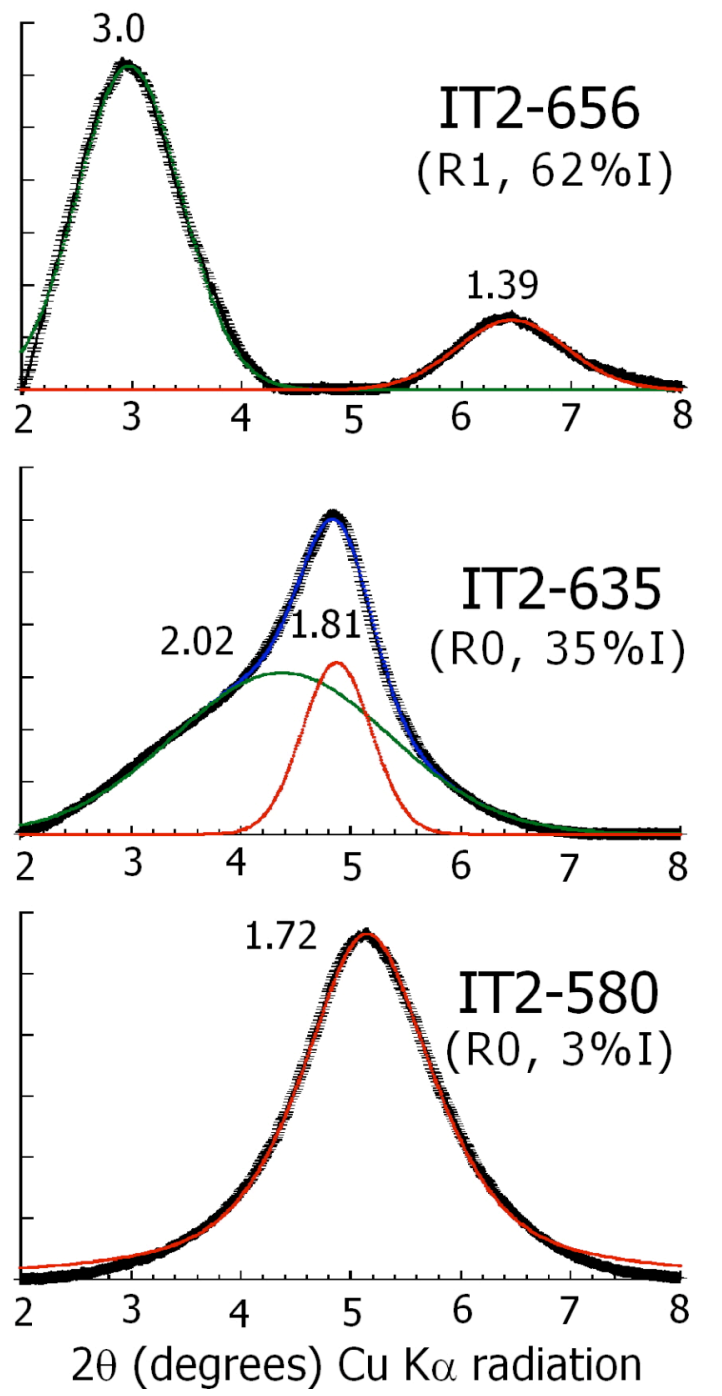

Shinzan
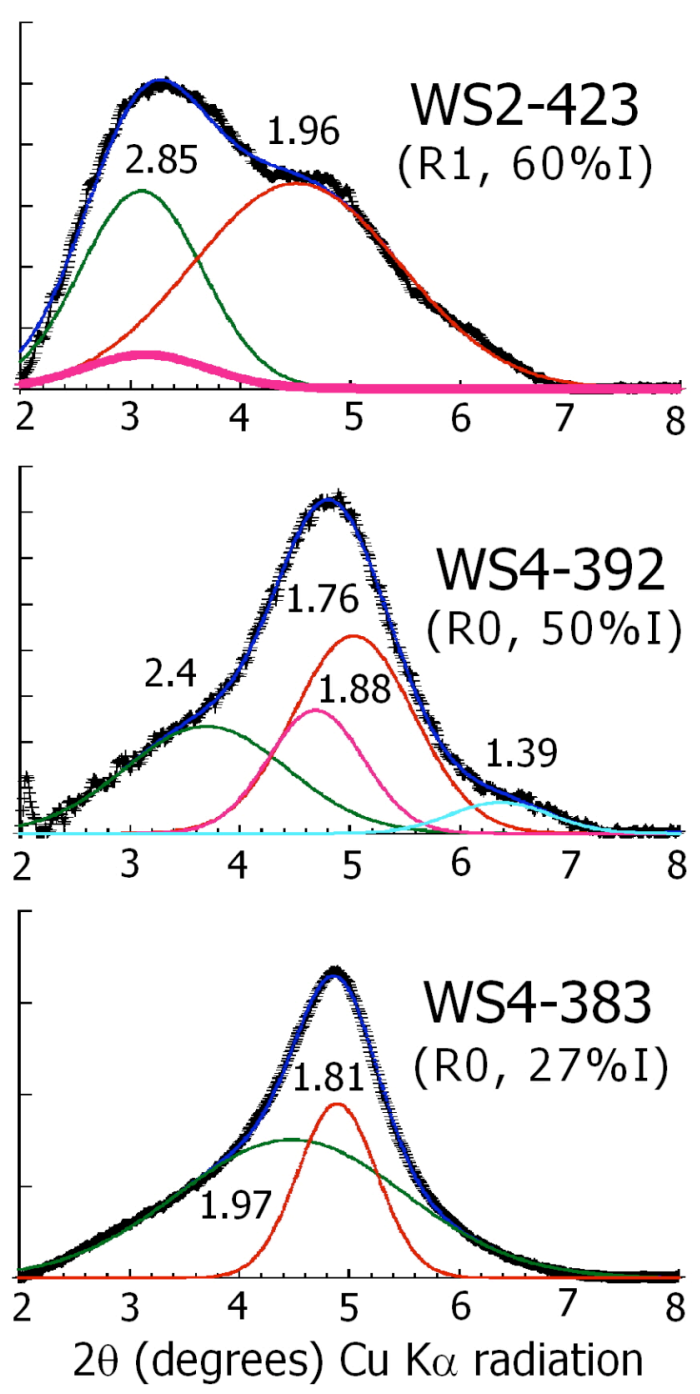

Figure 10 


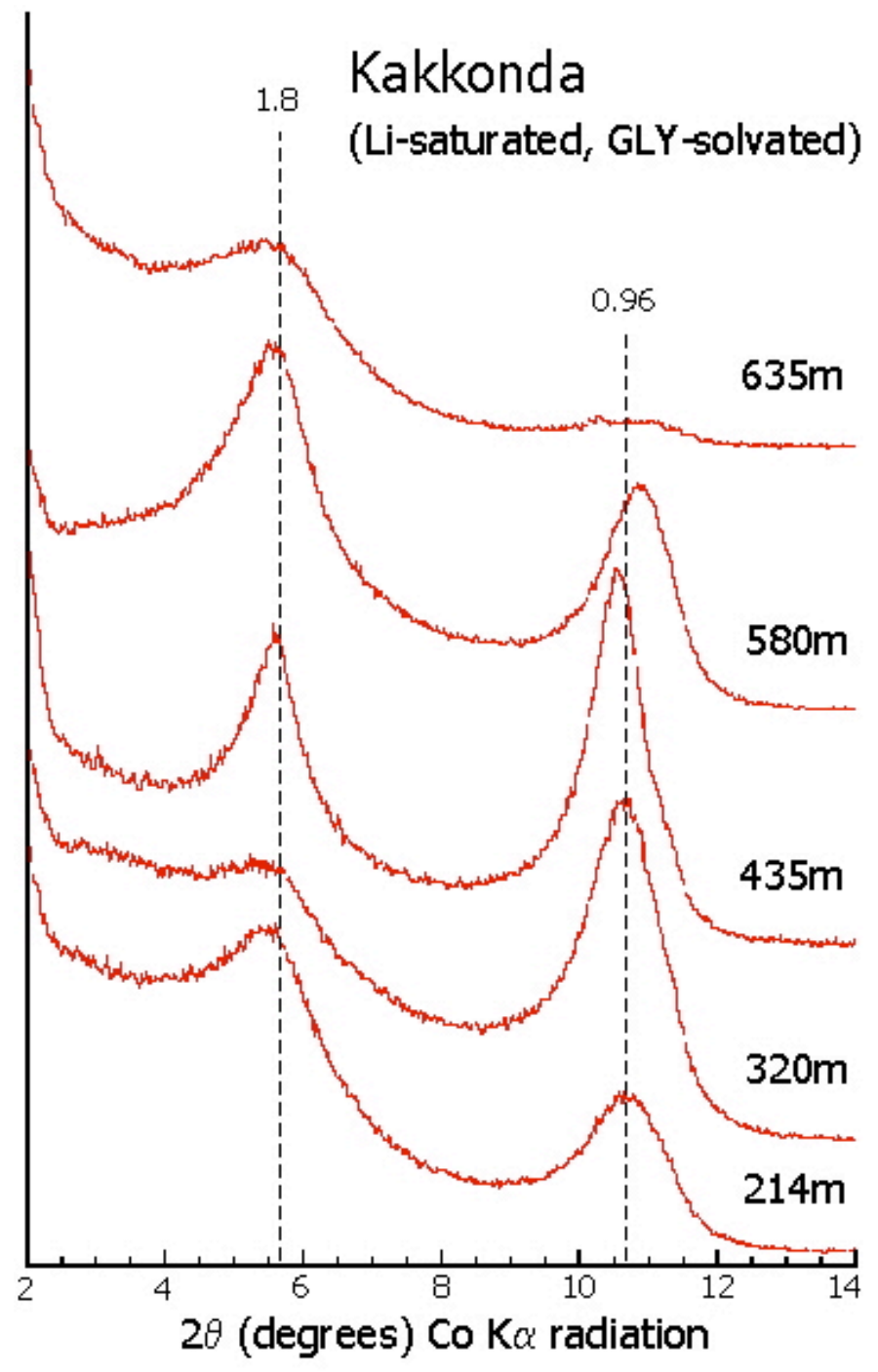

Figure 11 
Table 1. Chemical composition, \% I and formation temperature of Kakkonda I-S samples studied here (after Inoue et al., 2004)

\begin{tabular}{|c|c|c|c|c|c|c|c|c|c|c|c|}
\hline Samples & IT2-214 & IT2-320 & IT2-435 & IT2-580 & IT2-635 & IT2-645 & IT2-656 & IT2-690 & IT2-700 & IT2-756 & IT2-919 \\
\hline Teterahedral Si & 3.93 & 4.00 & 3.90 & 3.75 & 3.71 & 3.48 & 3.47 & 3.37 & 3.44 & 3.43 & 3.36 \\
\hline $\mathrm{Al}$ & 0.07 & 0.00 & 0.10 & 0.25 & 0.29 & 0.52 & 0.53 & 0.63 & 0.56 & 0.57 & 0.64 \\
\hline Octahedral Al & 1.37 & 1.33 & 1.32 & 1.62 & 1.66 & 1.83 & 1.77 & 1.84 & 1.84 & 1.79 & 1.70 \\
\hline $\mathrm{Fe}^{3+}$ & 0.32 & 0.26 & 0.35 & 0.19 & 0.13 & 0.08 & 0.10 & 0.08 & 0.06 & 0.01 & 0.10 \\
\hline $\mathrm{Mg}$ & 0.23 & 0.32 & 0.28 & 0.19 & 0.19 & 0.09 & 0.10 & 0.07 & 0.09 & 0.22 & 0.25 \\
\hline Interlayer $\mathrm{Ca}$ & 0.05 & 0.02 & 0.04 & 0.01 & 0.06 & 0.02 & 0.01 & 0.01 & 0.01 & 0.01 & 0.00 \\
\hline $\mathrm{Na}$ & 0.26 & 0.34 & 0.34 & 0.42 & 0.37 & 0.30 & 0.23 & 0.22 & 0.22 & 0.14 & 0.08 \\
\hline $\mathrm{K}$ & 0.04 & 0.08 & 0.05 & 0.03 & 0.17 & 0.26 & 0.44 & 0.44 & 0.46 & 0.59 & 0.68 \\
\hline $\begin{array}{l}\text { Layer charge } \\
{\left[/ \mathrm{O}_{10}(\mathrm{OH})_{2}\right]}\end{array}$ & 0.46 & 0.51 & 0.45 & 0.40 & 0.42 & 0.57 & 0.64 & 0.69 & 0.64 & 0.73 & 0.74 \\
\hline$\% \mathrm{I}$ & 5 & 13 & 2 & 4 & 45 & $45+60 *$ & 62 & 57 & 62 & 75 & $>95$ \\
\hline $\begin{array}{l}\text { Formation Temp. } \\
\qquad\left({ }^{\circ} \mathrm{C}\right)^{* *}\end{array}$ & 68 & 89 & 111 & 143 & 154 & 156 & 158 & 164 & 166 & 175 & 205 \\
\hline Impurities $* * *$ & $\mathrm{pl}$ & opal, cpt & opal, qz, sid & $\mathrm{qz}$ & $\mathrm{pl}, \mathrm{qz}$ & $\mathrm{qz}$ & $\mathrm{qz}$ & $\mathrm{qz}$ & $\mathrm{qz}$ & & $\mathrm{qz}, \mathrm{pl}$, cor \\
\hline
\end{tabular}

* A mixture of two phases

** The temperatures are those observed at present

*** pl: plagioclase, opal: opal-CT, cpt: clinoptilolite, qz: quartz, sid: siderite, ill: illite, ab: albite, cor: corrensite 
Table 2. Optimized structural parameters of Kakkonda I-S mixedlayer minerals

\begin{tabular}{|c|c|c|c|c|c|c|c|c|c|c|c|}
\hline Sample & \multicolumn{2}{|c|}{$\begin{array}{c}\text { Measurement } \\
\text { conditions }\end{array}$} & \multicolumn{2}{|c|}{ Proportions of i layers } & \multicolumn{3}{|c|}{$\begin{array}{c}\mathrm{d}_{001}(\mathrm{~nm}) \\
\text { Junction probability }\end{array}$} & $\mathrm{N}$ & K & $\mathrm{Fe}$ & $\begin{array}{l}R_{W P} \\
(\%)\end{array}$ \\
\hline \multirow{8}{*}{$435-\mathrm{m}$} & \multirow{4}{*}{\multicolumn{2}{|c|}{ Ca-AD }} & \multicolumn{2}{|c|}{$R=0$} & 0.998 & 1.515 & 1.25 & & & & \\
\hline & & & $\mathrm{W}_{\mathrm{I}}$ & 0.05 & & & & & & & \\
\hline & & & $\mathrm{W}_{\mathrm{s}}$ & 0.9 & & 0.9 & 0.05 & 10 & 1.5 & 0.5 & 22.87 \\
\hline & & & $\mathrm{W}_{\mathrm{v}}$ & 0.05 & & 0.9 & 0.05 & & & & \\
\hline & \multirow{4}{*}{\multicolumn{2}{|c|}{$\mathrm{Ca}-\mathrm{EG}$}} & \multicolumn{2}{|c|}{$R=0$} & 0.998 & 1.68 & 1.29 & & & & \\
\hline & & & $\mathrm{W}_{\mathrm{I}}$ & 0.05 & & & & & & & \\
\hline & & & $\mathrm{W}_{\mathrm{s}}$ & 0.9 & & 0.9 & 0.05 & 10 & 1.5 & 0.5 & 17.11 \\
\hline & & & & 0.05 & 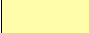 & 0.9 & 0.05 & & & & \\
\hline & & & & & 0.998 & 1.52 & 1.23 & & & & \\
\hline & & & $\mathrm{W}_{\mathrm{I}}$ & 0.03 & & & & & & & \\
\hline & & & $\mathrm{W}_{\mathrm{S}}$ & 0.88 & & 0.9 & 0.05 & 6.5 & 1.5 & 0.4 & 18.91 \\
\hline 580 & & & $\mathrm{~W}_{\mathrm{v}}$ & 0.09 & & 0.9 & 0.05 & & & & \\
\hline $500-111$ & & & & & 0.998 & 1.68 & 1.4 & & & & \\
\hline & & & $\mathrm{W}_{\mathrm{I}}$ & 0.03 & & & & & & & \\
\hline & & & $\mathrm{W}_{\mathrm{s}}$ & 0.92 & & 0.92 & 0.05 & 7 & 1.5 & 0.4 & 19.13 \\
\hline & & & $\mathrm{W}_{\mathrm{v}}$ & 0.05 & & 0.92 & 0.05 & & & & \\
\hline & & & & & 0.998 & 1.515 & 1.25 & & & & \\
\hline & & & $\mathrm{W}_{\mathrm{I}}$ & 0.35 & & & & & & & \\
\hline & & & $\mathrm{W}_{\mathrm{S}}$ & 0.55 & & 0.55 & 0.1 & 15 & 1.5 & 0.25 & 19.65 \\
\hline 635 & & & $\mathrm{~W}_{\mathrm{V}}$ & 0.1 & & 0.55 & 0.1 & & & & \\
\hline $05 J-11$ & & & & & 0.998 & 1.675 & & & & & \\
\hline & & & $\mathrm{W}_{\mathrm{I}}$ & 0.35 & & & & & & & \\
\hline & & & $\mathrm{W}_{\mathrm{s}}$ & 0.65 & & 0.65 & 0 & 10 & 1.5 & 0.25 & 13.35 \\
\hline & & & $\mathrm{W}_{\mathrm{v}}$ & 0 & & 0.65 & 0 & & & & \\
\hline & & & & & 0.998 & 1.515 & 1.25 & & & & \\
\hline & 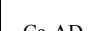 & Phase A & $\mathrm{W}_{\mathrm{I}}$ & 0.35 & & & & & & & \\
\hline & Ca-AD & $83 \%$ & $\mathrm{~W}_{\mathrm{s}}$ & 0.55 & & 0.55 & 0.1 & 25 & 1.5 & 0.15 & \\
\hline & & & $\mathrm{W}_{\mathrm{v}}$ & 0.1 & & 0.55 & 0.1 & & & & \\
\hline & & & & & 0.998 & 1.515 & 1.25 & & & & 16.37 \\
\hline & $\mathrm{Ca}-\mathrm{AD}$ & Phase B & $\mathrm{W}_{\mathrm{I}}$ & 0.5 & & & & & & & \\
\hline & & $17 \%$ & $\mathrm{~W}_{\mathrm{s}}$ & 0.4 & & 0.12 & 0.03 & 8 & 1.5 & 0.15 & \\
\hline 615 & & & $\mathrm{~W}_{\mathrm{V}}$ & 0.1 & & 0.12 & 0.03 & & & & \\
\hline $045-111$ & & & & & 0.998 & 1.675 & & & & & \\
\hline & $C_{-} \mathrm{EG}$ & Phase A & $\mathrm{W}_{\mathrm{I}}$ & 0.35 & & & & & & & \\
\hline & Ca-LU & $80 \%$ & $\mathrm{~W}_{\mathrm{S}}$ & 0.65 & & 0.65 & 0 & 12 & 1.5 & 0.15 & \\
\hline & & & $\mathrm{W}_{\mathrm{v}}$ & 0 & & 0 & 0 & & & & \\
\hline & & & & & 0.998 & 1.675 & & & & & 8.89 \\
\hline & $\mathrm{Ca}-\mathrm{EG}$ & Phase B & $\mathrm{W}_{\mathrm{I}}$ & 0.5 & & & & & & & \\
\hline & Ca-EG & $20 \%$ & $\mathrm{~W}_{\mathrm{s}}$ & 0.5 & & 0.15 & 0 & 7 & 1.5 & 0.15 & \\
\hline & & & $\mathrm{W}_{\mathrm{V}}$ & 0 & & 0 & 0 & & & & \\
\hline & & & & & 0.998 & 1.515 & 1.25 & & & & \\
\hline & & & $\mathrm{W}_{1}$ & 0.55 & & & & & & & \\
\hline & & & $\mathrm{W}_{\mathrm{S}}$ & 0.4 & & 0.15 & 0.05 & 15 & 1.7 & 0.15 & 24.44 \\
\hline $690-\mathrm{m}$ & & & & 0.05 & & 0.4 & 0.05 & & & & \\
\hline $090-m$ & & & & & 0.998 & 1.68 & & & & & \\
\hline & & & $\mathrm{W}_{\mathrm{I}}$ & 0.55 & & & & & & & \\
\hline & & & $\mathrm{W}_{\mathrm{S}}$ & 0.4 & & 0.15 & 0.05 & 15 & 1.7 & 0.15 & 16.13 \\
\hline & & & $\mathrm{W}_{\mathrm{v}}$ & 0.05 & & 0.4 & 0.05 & & & & \\
\hline & & & & & 0.998 & 1.515 & 1.25 & & & & \\
\hline & & & $\mathrm{W}_{\mathrm{I}}$ & 0.6 & 0.55 (SII & S), 0.075 & (SIV), & & & & \\
\hline & & & $\mathrm{W}_{\mathrm{S}}$ & 0.35 & 0.55 (VIS) & ), 0.075 & VIV) all & 10 & 1.7 & 0 & 28.22 \\
\hline 700 & & & $\mathrm{~W}_{\mathrm{v}}$ & 0.05 & other pro & obabiliti & s are 0 & & & & \\
\hline (100-111 & & & & & 0.998 & 1.68 & & & & & \\
\hline & & & $\mathrm{W}_{\mathrm{I}}$ & 0.6 & & & & & & & \\
\hline & & & $\mathrm{W}_{\mathrm{s}}$ & 0.4 & $0.75(1$ & IIS) all o & & 10 & 1.7 & 0 & 17.52 \\
\hline & & & $\mathrm{W}_{\mathrm{v}}$ & 0 & & & & & & & \\
\hline & & & R1 MPL & 2 MPDO & 0.998 & 1.515 & 1.25 & & & & \\
\hline & & & $\mathrm{W}_{\mathrm{I}}$ & 0.85 & & & & & & & \\
\hline & & & $\mathrm{W}_{\mathrm{S}}$ & 0.125 & 0.084 & SIIS) all & other & 19 & 1.5 & 0 & 18.23 \\
\hline 756-m & & & $\mathrm{W}_{\mathrm{V}}$ & 0.025 & & & & & & & \\
\hline & & & R1 MPL & 2 MPDO & 0.998 & 1.68 & 1.29 & & & & \\
\hline & & & & & & & & & & & \\
\hline & & & $\mathrm{W}_{\mathrm{I}}$ & 0.85 & & & & & & & \\
\hline & & & $\mathrm{W}_{\mathrm{s}}$ & 0.125 & 0.084( & $\begin{array}{l}\text { SIIS) all } \\
\text { bilities }\end{array}$ & other & 20 & 1.5 & 0 & 24.58 \\
\hline & & & $\mathrm{W}_{\mathrm{v}}$ & 0.025 & & & & & & & \\
\hline & & : basal spac & ing of a give & & & mean nur & nber of lay & & & & \\
\hline & w & : proportior & of i layer & & & fixed $\mathrm{K}$ i & ins $\left(/ \mathrm{O}_{20}(\mathrm{C}\right.$ & I) $)_{4}$ ) in & e inter & & \\
\hline & $\mathrm{Ca}-\mathrm{Al}$ & :Ca-satura & ed, air-dried & & $\mathrm{Fe}$ : & Fe conter & $\mathrm{t} /\left(\mathrm{O}_{20} \mathrm{OH}\right.$ & 4) in oc & edral s. & & \\
\hline & $\mathrm{Ca}-\mathrm{EC}$ & :Ca-satura & ed, EG-solv & & $\mathrm{R}_{\mathrm{WP}}$ : & residual $\mathrm{f}$ & $\left(a c t r^{24}\right.$ & & & & \\
\hline & shadowed ar & : junction pr & babilities & & MPDO : & maximun & possible & gree o & $\mathrm{der}^{331}$ & & \\
\hline
\end{tabular}


Table 3. Occurrence probabilities of layers, layer doublets, triplets, and quartets in I-S crystallites calculated from junction probabilities for EG-saturated samples

\begin{tabular}{|c|c|c|c|c|c|c|c|c|}
\hline \multirow{2}{*}{$\begin{array}{c}\text { Layer } \\
\text { sequence }\end{array}$} & \multirow{2}{*}{$\begin{array}{c}\text { 435-m } \\
\text { R0 }\end{array}$} & \multirow{2}{*}{$\begin{array}{c}580-\mathrm{m} \\
\text { R0 }\end{array}$} & \multirow{2}{*}{$\begin{array}{c}\text { 635-m } \\
\text { R0 }\end{array}$} & \multicolumn{2}{|c|}{$645-\mathrm{m}$} & \multirow{2}{*}{$\begin{array}{c}\text { 690-m } \\
\text { R1 }\end{array}$} & \multirow{2}{*}{$\begin{array}{c}\text { 700-m } \\
\text { R2 }\end{array}$} & \multirow{2}{*}{$\begin{array}{c}\text { 756-m } \\
\text { R3 }\end{array}$} \\
\hline & & & & R0 & R1 & & & \\
\hline I & 0.050 & 0.030 & 0.350 & 0.500 & 0.500 & 0.550 & 0.600 & 0.850 \\
\hline $\mathrm{S}$ & 0.900 & 0.880 & 0.650 & 0.400 & 0.500 & 0.400 & 0.400 & 0.125 \\
\hline $\mathrm{V}$ & 0.050 & 0.090 & 0.000 & 0.100 & 0.000 & 0.050 & 0.000 & 0.025 \\
\hline II & 0.003 & 0.001 & 0.123 & 0.250 & 0.075 & 0.203 & 0.200 & 0.700 \\
\hline IS & 0.045 & 0.026 & 0.228 & 0.200 & 0.425 & 0.320 & 0.400 & 0.125 \\
\hline IV & 0.003 & 0.003 & 0.000 & 0.050 & 0.000 & 0.028 & 0.000 & 0.026 \\
\hline SS & 0.810 & 0.774 & 0.423 & 0.160 & 0.075 & 0.060 & 0.000 & 0.000 \\
\hline III & 0.001 & 0.000 & 0.043 & 0.125 & 0.011 & 0.075 & 0.050 & 0.576 \\
\hline IIS & 0.002 & 0.001 & 0.080 & 0.100 & 0.064 & 0.118 & 0.150 & 0.103 \\
\hline SIS & 0.041 & 0.023 & 0.148 & 0.080 & 0.361 & 0.186 & 0.100 & 0.018 \\
\hline VIV & 0.041 & 0.000 & 0.000 & 0.005 & 0.000 & 0.001 & 0.000 & 0.000 \\
\hline IIII & 0.000 & 0.000 & 0.015 & 0.063 & 0.002 & 0.027 & 0.012 & 0.466 \\
\hline IIIS & 0.000 & 0.000 & 0.028 & 0.050 & 0.010 & 0.043 & 0.037 & 0.110 \\
\hline SIIS & 0.002 & 0.001 & 0.052 & 0.040 & 0.065 & 0.069 & 0.113 & 0.010 \\
\hline VIIV & 0.000 & 0.000 & 0.000 & 0.003 & 0.000 & 0.001 & 0.000 & 0.000 \\
\hline
\end{tabular}

